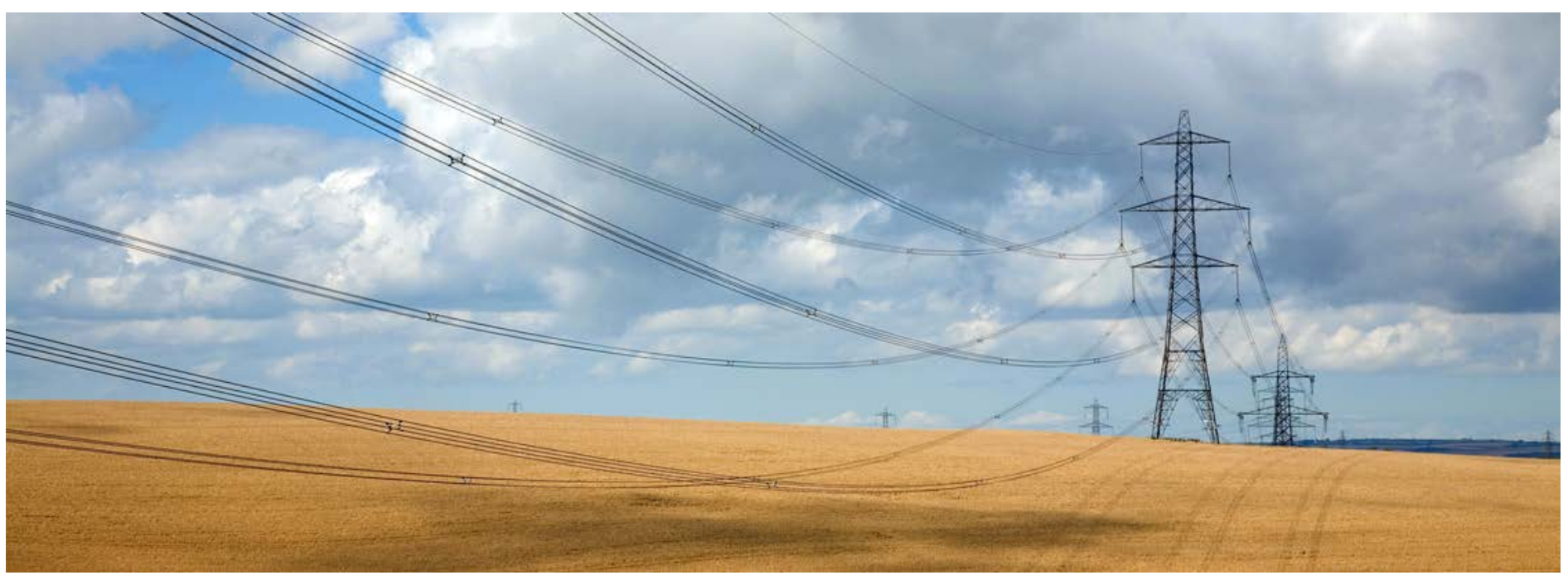

\title{
Geospatial Analysis of Renewable Energy Technical Potential on Tribal Lands
}

E. Doris, A. Lopez, and D. Beckley

National Renewable Energy Laboratory 


\section{NOTICE}

This report was prepared as an account of work sponsored by an agency of the United States government. Neither the United States government nor any agency thereof, nor any of their employees, makes any warranty, express or implied, or assumes any legal liability or responsibility for the accuracy, completeness, or usefulness of any information, apparatus, product, or process disclosed, or represents that its use would not infringe privately owned rights. Reference herein to any specific commercial product, process, or service by trade name, trademark, manufacturer, or otherwise does not necessarily constitute or imply its endorsement, recommendation, or favoring by the United States government or any agency thereof. The views and opinions of authors expressed herein do not necessarily state or reflect those of the United States government or any agency thereof.

Available electronically at www.osti.gov/bridge

Available for a processing fee to U.S. Department of Energy and its contractors, in paper, from:

U.S. Department of Energy

Office of Scientific and Technical Information

P.O. Box 62

Oak Ridge, TN 37831-0062

phone: 865.576 .8401

fax: 865.576 .5728

email: reports@adonis.osti.gov

Available for sale to the public, in paper, from:

U.S. Department of Commerce

National Technical Information Service

5285 Port Royal Road

Springfield, VA 22161

phone: 800.553 .6847

fax: 703.605 .6900

email: orders@ntis.fedworld.gov

online ordering: www.ntis.gov/ordering.htm

energy.gov/indianenergy | indianenergy@hq.doe.gov

DOE/IE-0013 • February 2013

Printed with a renewable-source ink on paper containing at least 50\% wastepaper, including $10 \%$ post consumer waste. 


\section{Acknowledgments}

This report is made possible by and at the direction of the DOE Office of Indian Energy Policy and Programs. The National Renewable Energy Laboratory (NREL) would like to thank our colleagues at NREL who reviewed this report for accuracy: Nate Blair, Billy Roberts, Gian Porro, Marguerite Kelly, and Ann Brennan. We would also like to thank our external partners who also reviewed provided insights throughout paper development: Paul Dearhouse, Royce Stewart, Tracey LeBeau, and Pilar Thomas. Finally, we'd like to thank Daniel Hillman for developing the summary tables of data and Rachel Sullivan for providing editorial support.

\section{About the DOE Office of Indian Energy}

The U.S. Department of Energy Office of Indian Energy Policy and Programs was established by Congress to provide Tribes, Alaska Native villages, and eligible tribal entities with technical and financial assistance that promotes energy development and energy infrastructure on tribal lands.

In direct response to the requests of Tribes and Alaska Native villages, the DOE Office of Indian Energy has designed key programs to provide Indian Country with the knowledge needed to make informed energy decisions-decisions with the power to help stabilize energy costs, enhance energy security, strengthen economic development and tribal energy infrastructure, and promote tribal self-determination.

By providing reliable, accurate information and expert technical assistance, the Office of Indian Energy empowers Indian Country to make decisions needed to bring about the next generation of energy development on their lands.

The office supports those decisions by offering technical support related to technology and project development, financial assistance, and real-time training. It also works to advance tribal visions for a sustainable energy future by promoting four key goal areas: project development, job creation, grid infrastructure, and energy security. 


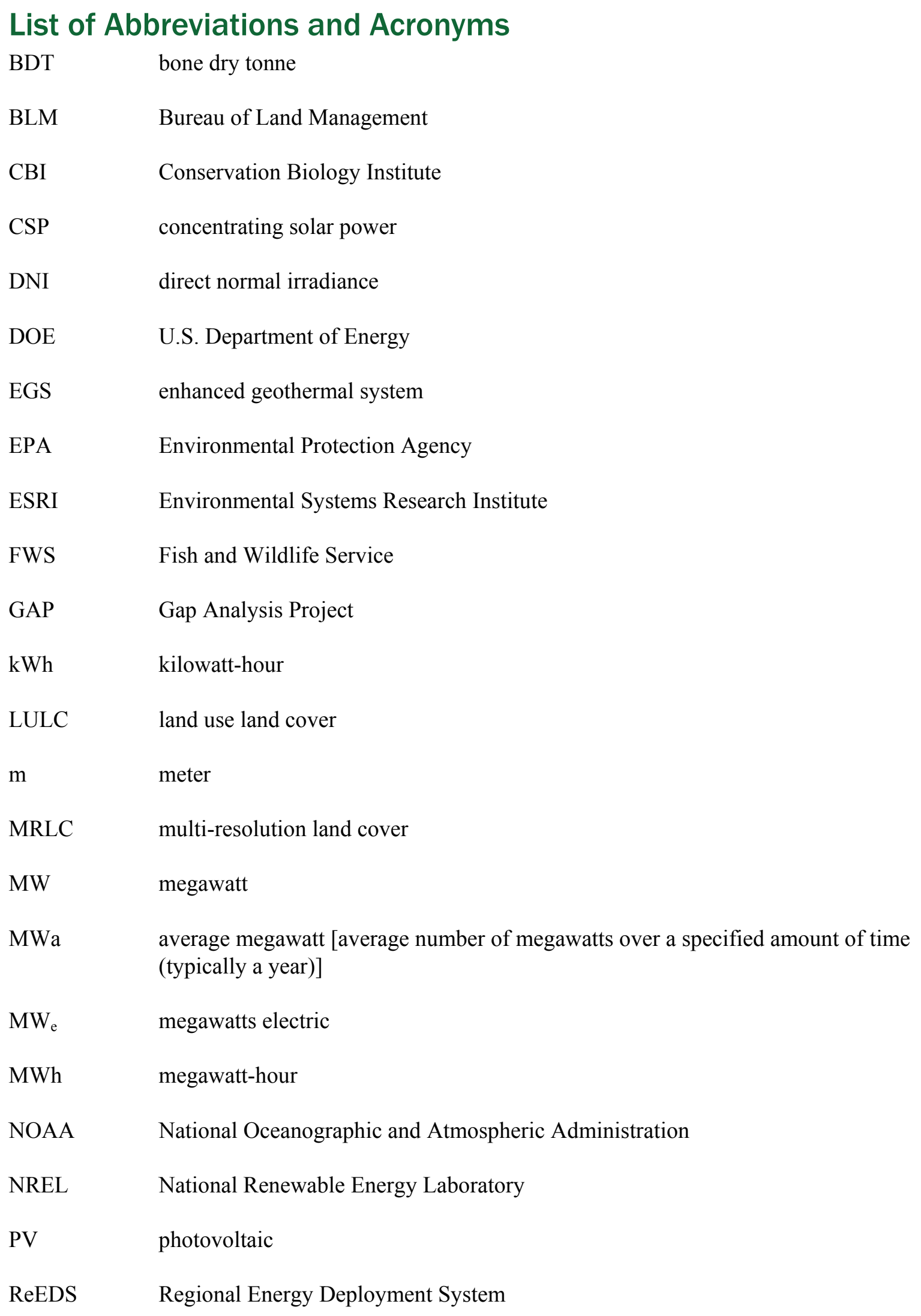




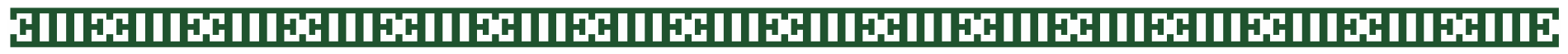

RPS renewable portfolio standard

SAM System Advisor Model

SMU Southern Methodist University

USFS United States Forest Service

USGS United States Geological Survey 


\section{Table of Contents}

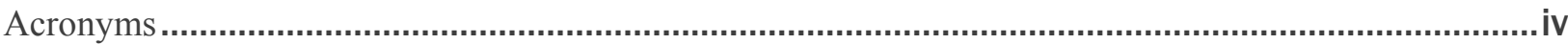

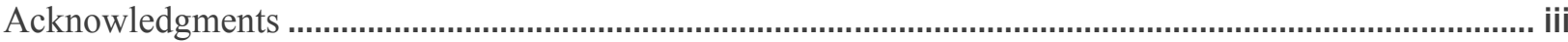

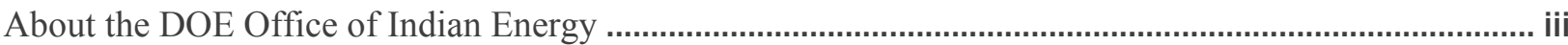

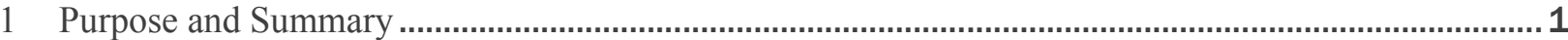

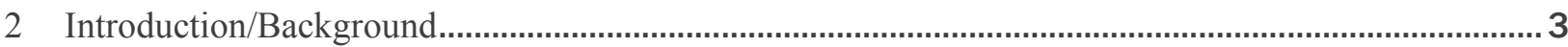

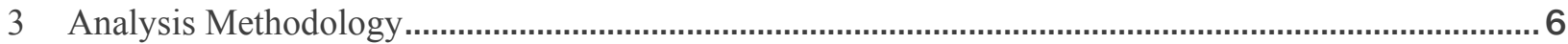

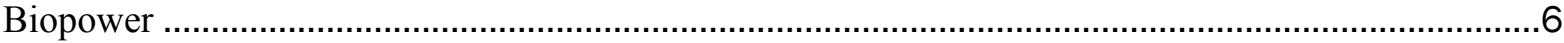

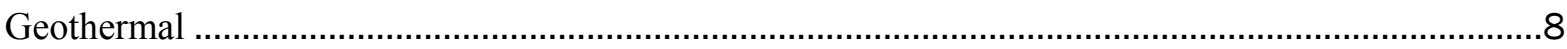

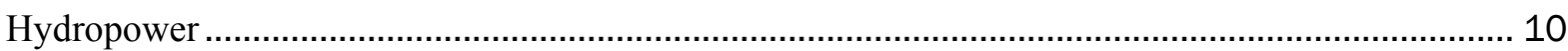

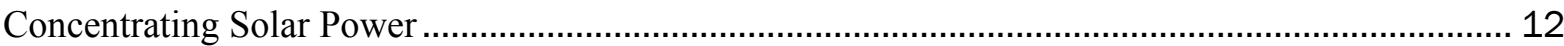

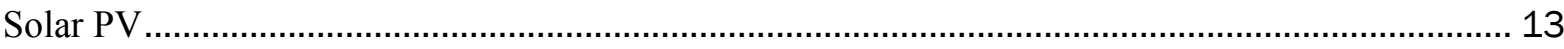

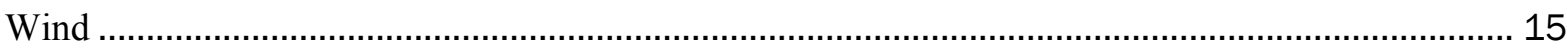

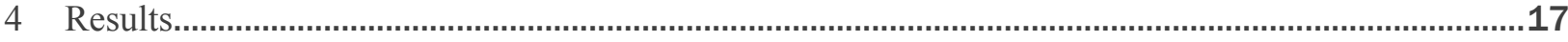

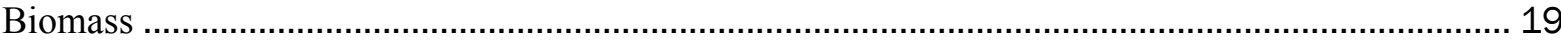

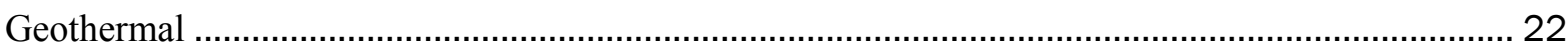

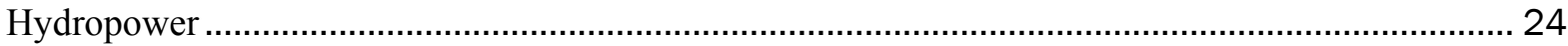

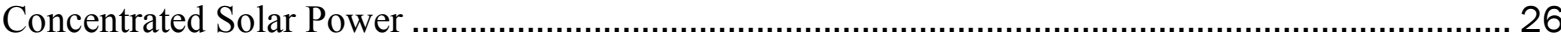

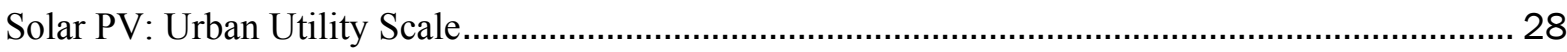

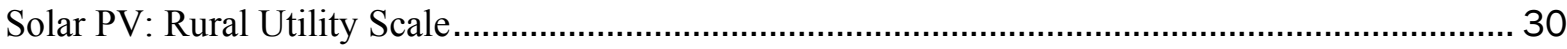

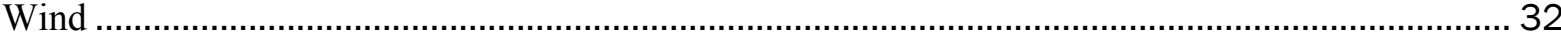

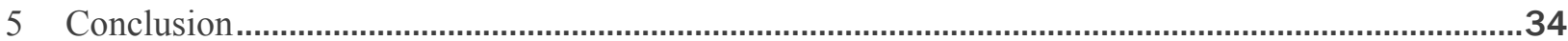

$6 \quad$ References

Appendix 1. Exclusions and Constraints, Capacity Factors, and Power Densities .....................................36

Appendix 2. Technical Potential by Tribal Lands for Renewable Resources .............................................43 


\section{List of Figures}

Figure 1. Levels of renewable energy potential defined …....................................................................

Figure 2. Tribal lands biomass generation potential ............................................................................. 19

Figure 3. Tribal lands geothermal (EGS and hydrothermal) generation potential ..................................22

Figure 4. Tribal lands hydropower generation potential ...................................................................24

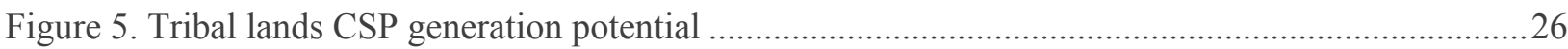

Figure 6. Tribal lands PV utility-scale urban generation potential .....................................................28

Figure 7. Tribal lands PV utility-scale rural generation potential ........................................................30

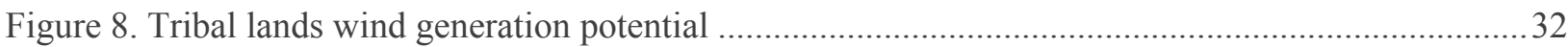




\section{List of Tables}

Table S-1. Summary of Tribal Technical Potential by Capacity and Generation .......................................2

Table 4-1. Summary of Tribal Technical Potential by Capacity and Generation .....................................18

Table 4-2. Top 25 Tribal Lands by Technical Potential for Biopower Generation from Solid Residues ...20

Table 4-3. Top 25 Tribal Lands by Technical Potential for Biopower Generation from Gaseous Residues21

Table 4-4. Top 25 Tribal Lands by Technical Potential for Hydrothermal Geothermal Generation ..........23

Table 4-5. Top 25 Tribal Lands by Technical Potential for Hydropower Generation ..............................25

Table 4-6. Top 25 Tribal Lands by Technical Potential for CSP Generation ..........................................27

Table 4-7. Top 25 Tribal Lands by Technical Potential for Urban Utility-Scale PV Generation ..............29

Table 4-8. Top 25 Tribal Lands by Technical Potential for Rural Utility-Scale PV Generation ................31

Table 4-9. Top 25 Tribal Lands by Technical Potential for Wind Electricity Generation.........................33

Table A-1. Exclusions and Constraints for Urban Utility-Scale Photovoltaics .......................................36

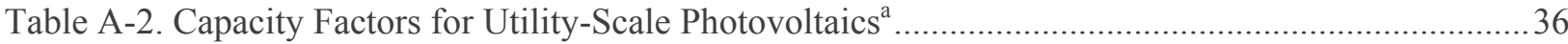

Table A-3. Exclusions and Constraints for Rural Utility-Scale Photovoltaics and Concentrating Solar

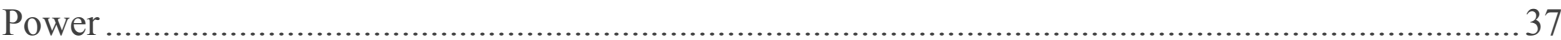

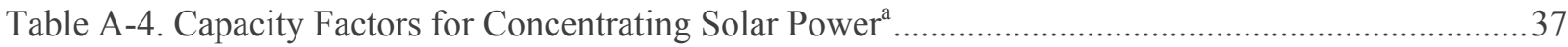

Table A-5. Exclusions and Constraints for Onshore Wind Power ...........................................................38

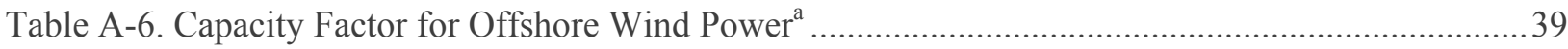

Table A-7. Conversion of Offshore Wind Speeds at 90 Meters to Power Classes ${ }^{\mathrm{a}}$..................................39

Table A-8. Exclusions and Constraints for Offshore Wind Power ${ }^{\mathrm{a}}$.....................................................40

Table A-9. Exclusions and Constraints for Enhanced Geothermal Systems ${ }^{\mathrm{a}}$........................................41

Table A-10. Power Densities for Enhanced Geothermal Systems ${ }^{\mathrm{a}}$ …..................................................42

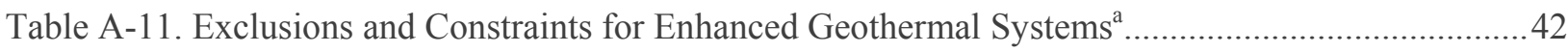

Table A2-1. Tribal Renewable Energy Potential—Hydrothermal, Hydropower, and Biopower ...............43 


\section{Purpose and Summary}

This paper uses an established geospatial methodology to estimate the technical potential for renewable energy on tribal lands for the purpose of allowing Tribes to prioritize the development of renewable energy resources either for community-scale on-tribal-land use or for revenue-generating electricity sales. A graphical summary of the report and its findings is available:

http://www.nrel.gov/docs/fy13osti/57048.pdf.

Geospatial methodology is an approach to analyzing information that incorporates data that has a geographic component and allows for a more refined analysis of technical potential for all Tribes by parsing it to individual tribal lands. Technical potential is narrowing of resource potential to exclude topographic constraints and land-use constraints while taking into account system performance (for a more detailed definition, see the Introduction/Background section).

Although this analysis provides insight into the potential for renewable energy development on tribal lands, further identification and removal of barriers for tribal renewable energy development and the processes for overcoming them is needed to lead to actual increases in renewable energy generation on tribal lands. The next step for Tribes that wish to pursue projects is to determine the market or developable potential of renewable energy. This includes assessing broader tribal interests in development (e.g., scale of project, purpose of project, cultural sensitivity avoidance); understanding the energy environment in which the project would function as a way of assessing potential project viability and economics; and working with the local utility and regulatory authorities to understand renewable energy needs.

The DOE Office of Indian Energy Policy and Programs offers a number of resources to support the development of renewable energy resources, including a detailed energy resource library containing documents that provide information on project development, training on renewable technology attributes, a step-by-step process for project development and financing options, and the provision of technical assistance to Tribes in need of expertise in project development and financing. Information on available assistance can be found on the DOE Office of Indian Energy website: www.energy.gov/indianenergy.

Only a few nationwide tribal examples exist to extrapolate successful renewable energy development models, and this report intends to provide Tribes with basic information regarding the development potential for renewable energy - biomass, geothermal, hydroelectric, solar, and wind-on tribal lands. It provides detailed renewable energy potential information by tribal territory and resource throughout the United States in order to help Tribes identify areas where development may be an option, and where tribal or private investment in renewable energy may assist in achieving a Tribe's economic development, energy savings, or self-sufficiency goals.

Overall, the analysis shows that the technical potential on tribal lands is about $6 \%$ of the total national technical generation potential (Table S-1). This is disproportionately larger than the $2 \%$ tribal lands in the United States, indicating an increased potential density for renewable energy development on tribal lands. 
Table S-1. Summary of Tribal Technical Potential by Capacity and Generation

\begin{tabular}{|c|c|c|c|c|c|c|}
\hline Technology & $\begin{array}{l}\text { Tribal } \\
\text { Capacitya } \\
\text { Potentialb } \\
(\mathrm{MW})\end{array}$ & $\begin{array}{l}\text { National } \\
\text { Capacity } \\
\text { Potentialc } \\
\text { (MW) }\end{array}$ & $\begin{array}{l}\text { Tribal } \\
\text { Generation } \\
\text { Potential (MWh) }\end{array}$ & $\begin{array}{l}\text { National } \\
\text { Generationa } \\
\text { Potential (MWh) }\end{array}$ & $\begin{array}{l}\% \text { of } \\
\text { National } \\
\text { Capacity }\end{array}$ & $\begin{array}{l}\% \text { of } \\
\text { National } \\
\text { Generation }\end{array}$ \\
\hline $\begin{array}{l}\text { Solar PV } \\
\text { (Utility-Scale, } \\
\text { Rural) }\end{array}$ & $6,888,339$ & $152,973,829$ & $14,322,522,713$ & $280,613,216,903$ & $4.5 \%$ & $5.1 \%$ \\
\hline $\begin{array}{l}\text { Solar PV } \\
\text { (Utility-Scale, } \\
\text { Urban) }\end{array}$ & 8,199 & $1,217,699$ & $17,578,618$ & $2,231,693,746$ & $0.7 \%$ & $0.8 \%$ \\
\hline Solar CSP & $1,818,185$ & $38,066,401$ & $6,139,851,743$ & $116,146,244,587$ & $4.8 \%$ & $5.3 \%$ \\
\hline $\begin{array}{l}\text { Wind }(80 \mathrm{~m} \\
\text { height, >=30\% } \\
\text { GCF) }\end{array}$ & 374,505 & $10,954,759$ & $1,146,044,229$ & $32,784,004,656$ & $3.4 \%$ & $3.5 \%$ \\
\hline $\begin{array}{l}\text { Geothermal } \\
\text { (EGS) }\end{array}$ & 763,252 & $3,975,735$ & $6,017,487,000$ & $31,344,696,024$ & $19.2 \%$ & $19.2 \%$ \\
\hline $\begin{array}{l}\text { Geothermal } \\
\text { (Hydrothermal) }\end{array}$ & 641 & 30,033 & $5,050,724$ & $236,780,000$ & $2.1 \%$ & $2.1 \%$ \\
\hline $\begin{array}{l}\text { Biomass } \\
\text { (Solid) }\end{array}$ & 551 & 50,707 & $4,340,642$ & $399,774,091$ & $1.1 \%$ & $1.1 \%$ \\
\hline $\begin{array}{l}\text { Biomass } \\
\text { (Gaseous) }\end{array}$ & 85 & 11,232 & 673,465 & $88,551,445$ & $0.8 \%$ & $0.8 \%$ \\
\hline Hydropower & 1,687 & 60,000 & $7,390,196$ & $258,953,000$ & $2.8 \%$ & $2.9 \%$ \\
\hline Totalb & $9,855,444$ & $207,340,394$ & $27,660,939,330$ & $464,103,914,451$ & $4.8 \%$ & $6.0 \%$ \\
\hline
\end{tabular}

${ }^{\mathrm{a}}$ Capacity is the nameplate capacity of a power plant. Generation is the amount of MWh produced given average run times.

${ }^{\mathrm{b}}$ Technical potential calculated for each technology individually and does not account for overlap (i.e., the same land area may be identified with potential for wind and solar, and would be counted twice in the total). Some technologies may be compatible with mutual development.

${ }^{\mathrm{c}}$ Lopez, A. et al. (2012). U.S. Renewable Energy Technical Potentials: A GIS-Based Analysis. NREL/TP-6A20-51946. Golden, CO:

National Renewable Energy Laboratory. 


\section{Introduction/Background}

While other estimates of renewable energy potential on tribal lands exist, the strength of this style of estimation of resources is the use of up-to-date geospatial data for a more accurate representation of available resources. This is the first paper of its kind to use geospatial analysis to estimate the technical potential of renewable energy development on tribal lands. Technical potential is one of four levels of potential for renewable energy, as defined in Figure 1.

Key Assumptions

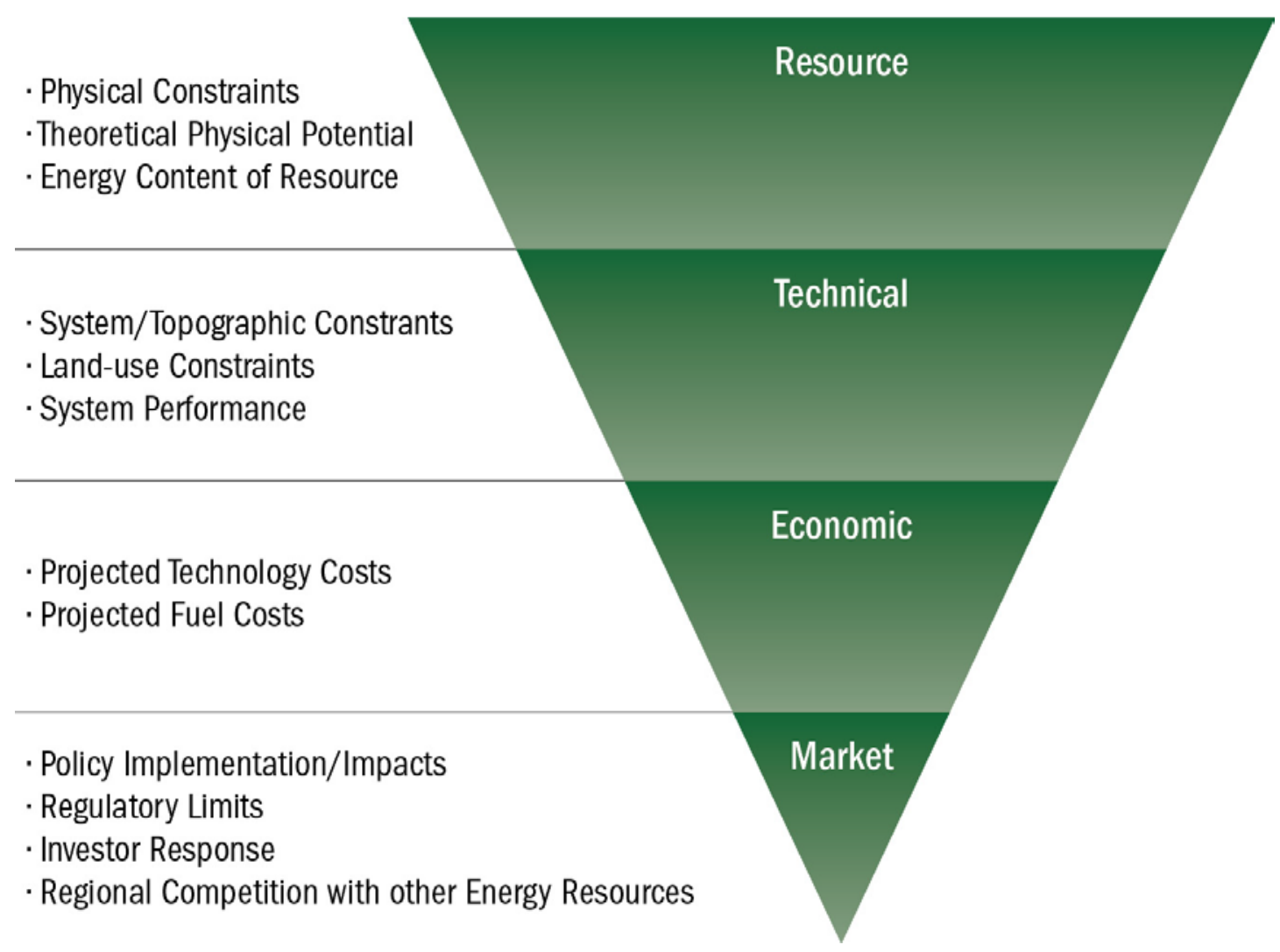

Figure 1. Levels of renewable energy potential defined

Source: Lopez et al. 2012, adapted from the DOE Office of Energy Efficiency and Renewable Energy (EERE) 2006

The renewable resources included in this report are described as follows in the remainder of this section. With the exception of enhanced geothermal systems, the scope of this work includes currently commercially available technologies within the definition of technical potential.

- Biopower. Biomass has been used for electric power generation for many years. It can be a costeffective, carbon-neutral dispatchable source of electrical power. Most biopower plants use directfired systems to generate electricity from biomass. They burn bioenergy feedstocks directly to produce steam. This steam drives a turbine, which turns a generator that converts the power into electricity. In some biomass industries, the spent steam from the power plant is also used for 
manufacturing processes or to heat buildings. Such combined heat and power systems greatly increase overall energy efficiency. Types of biomass include wood from various sources (beetle kill, slash, lumber waste), agricultural residues, animal and human waste (methane), and municipal solid waste and landfill gas.

- Geothermal. Geothermal technologies use heat from the Earth. Geothermal is a highly efficient method of providing electricity generation. High-temperature geothermal is ideal for power plant production levels, but low-temperature heat pumps can provide heating and cooling energy in any part of the United States. Lower-temperature resources are best suited for heat applications. Geothermal technologies exist commercially for either small-scale (distributed) or large-scale (central) electricity generation. As of 2012, 248 U.S. geothermal systems produce 9,057 mean megawatts of electricity (MWe). There are an estimated 30,033 MWe of undiscovered geothermal resources in the United States.

- Hydropower. Hydroelectricity refers to electricity generated through the use of the gravitational force of falling or flowing water, called hydropower. Both large and small-scale power producers can use hydropower technologies to produce clean electricity.

- Concentrating Solar Power. Concentrating solar power (CSP) technologies use mirrors to reflect and concentrate sunlight onto receivers that collect solar energy and convert it to heat. This thermal energy can then be used to produce electricity via a steam turbine or heat engine that drives a generator. While CSP offers a utility-scale, firm, dispatchable renewable energy option that can help meet demand for electricity, it is most economical in the southwestern United States. Factors that influence project economics are the cost of the technology, the quality of the solar resource, and the cost of the energy being displaced. CSP systems can be successfully installed on landfills, brownfields, and greenfields, with minimal disturbance to native vegetation and wildlife. Types of CSP systems include linear concentrator, dish/engine, power tower, and thermal storage.

- Solar PV. Photovoltaic (PV) technologies produce electricity directly from the energy of the sun. Small PV can provide electricity for homes, businesses, and remote power needs. Larger PV systems provide more electricity for contribution to the electric power system. PV technologies work in all parts of the United States, but economics are dependent on technology cost, quality of solar resource, and cost of energy being displaced. Flat plate is the most common PV array design, which uses flat-plate PV modules or panels that can be fixed in place or designed to track the movement of the sun. An off-grid, flat-plate solar PV system would be useful for remote locations or for self-sufficiency in the event of a power interruption. Concentrator PV systems use less solar cell material than other PV systems because they make use of relatively inexpensive materials such as plastic lenses and metal housings to capture the solar energy shining on a fairly large area and focus that energy onto a smaller area - the solar cell.

- Wind. Wind energy technologies use the kinetic energy in wind for practical purposes such as generating electricity, charging batteries, pumping water, and grinding grain. Most wind energy technologies can be used as stand-alone applications, connected to a utility power grid, or even combined with a PV system. Wind energy today is cost competitive in many locations throughout the United States. Utility-scale wind consists of a large number of turbines that are usually installed close together to form a wind farm that provides grid power. Several electricity providers use wind farms to supply power to their customers. Stand-alone turbines are typically used for water pumping or communications. However, homeowners and farmers in windy areas can also use small wind systems to generate electricity. 
For more information on renewable energy basics for Tribes, please search for "DOE Office of Indian Energy" at http://www.nterlearning.org.

Technical potential may not reflect the developable potential because it does not incorporate technology costs, competing land uses, transmission and infrastructure availability, or the policy, investor, or energy competitive environments. For Tribes, specific barriers can include a lack of:

- Replicable, successful examples of renewable energy development on tribal lands

- Clear ownership and tax equity structure options

- Access to transmission lines for movement of generated electricity

- Active markets for the buying and selling of renewable energy (often state policy driven through the use of renewable portfolio standards, or RPS)

While this report focuses on the identification of technical potential, there are resources for further understanding the market and economic potential for, and developing renewable energy resources on tribal lands at www.energy.gov/indianenergy, including a development document library, technical assistance, and education. 


\section{Analysis Methodology}

The basic methodology for determining the technical potential on tribal lands is to:

1) Determine the land area of the tribal lands

2) Estimate how much renewable resource exists within those areas

3) Estimate the amount of electricity that could possibly be produced from that land area, based on currently available technology for converting that resource into electricity.

Data on the area of tribal lands was downloaded from the Department of the Interior, Bureau of Indian Affairs and is dated 1999. This is the most recent and comprehensive database of federally recognized tribal lands. Due to lack of data resolution, only the exclusions listed in Appendix 1 are removed from the land within tribal areas. This analysis does not include removal of culturally sensitive areas or areas already in use that would not be appropriate for development.

The detailed methodology for determining the available resource, as well as the technical capabilities of the resource to electricity conversion technologies, is described in detail for each resource below.

\section{Biopower}

Biopower is the only technology analyzed using an alternative dataset than what was used in Lopez et al. 2012. The dataset used in Lopez et al. 2012 was county-based; it was determined that the resolution was too coarse for the relatively small tribal lands. Instead, land cover-based disaggregated estimates from the Biopower Atlas (http://maps.nrel.gov/biopower) are used. An area-weighted analysis was performed between the disaggregated datasets and the tribal lands to produce the total amount of gaseous and solid biomass on each tribal land.

Total estimated technical potential for gaseous biomass generation was estimated using 4.7 megawatthours (MWh)/tonne of $\mathrm{CH}_{4}$ (Lopez et al. 2012). This can be expressed as:

$$
\text { Biogasgen }_{t}=\sum_{k \in K} \frac{A I_{k, t}}{A_{t}} \cdot P_{k} \cdot C
$$

where

$\mathrm{t}=$ Tribal land

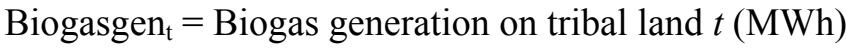

$\mathrm{AI}_{\mathrm{k}, \mathrm{t}}=$ Area of intersect between land cover polygon $k$ and tribal land $t$

$\mathrm{A}_{\mathrm{t}}=$ Area of tribal land $t$

$\mathrm{k}=$ Land-cover polygon 
$\mathrm{K}=$ Set of land-cover polygons

$\mathrm{P}_{\mathrm{k}}=\mathrm{CH}_{4}$ potential resource for land-cover polygon $k$ (tonnes)

$\mathrm{C}=$ Biogas $\mathrm{CH}_{4}$ conversion to energy $\left(4.7 \mathrm{MWh} /\right.$ tonne $\left.\mathrm{CH}_{4}\right)$

Estimated capacity for gaseous biomass was estimated by backing out the time component of the generation conversion and assuming a standard capacity factor of $90 \%$. This can be expressed as:

$$
\text { Biogascap }_{t}=\frac{\text { Biogasgen }_{t}}{\text { CFbio } \cdot 8760 h r}
$$

where

$\mathrm{t}=$ Tribal land

Biogascap $_{\mathrm{t}}=$ Biogas capacity on tribal land $t(\mathrm{MW})$

CFbio $=$ Capacity factor for biopower

Total estimated generation for solid biomass was estimated using 1.1 MWh/bone dry tonne (BDT) (Lopez et al. 2012). Expressed as:

$$
\text { Biosolidgen }_{t}=\sum_{k \in K} \frac{A I_{k, t}}{A_{t}} \cdot P_{k} \cdot C
$$

where

$\mathrm{t}=$ Tribal land

Biosolidgen $_{\mathrm{t}}=$ Solid biomass generation on tribal land $t(\mathrm{MWh})$

$\mathrm{AI}_{\mathrm{k}, \mathrm{t}}=$ Area of intersect between land cover polygon $k$ and tribal land $t$

$\mathrm{A}_{\mathrm{t}}=$ Area of tribal land $t$ 
$\mathrm{k}=$ Land-cover polygon

$\mathrm{K}=$ Set of land-cover polygons

$\mathrm{P}=$ Bone dry tonne potential resource

$\mathrm{C}=$ Solid biomass conversion to energy $(1.1 \mathrm{MWh} /$ bone dry tonne $)$

Estimated capacity for solid biomass was estimated by backing out the time component of the generation conversion and assuming a standard capacity factor of $90 \%$. This can be expressed as:

$$
\text { Biosolidcap }_{t}=\frac{\text { Biosolidgen }_{t}}{\text { CFbio } \cdot 8760 h r}
$$

where

$\mathrm{t}=$ Tribal land

Biosolidcap $_{\mathrm{t}}=$ Solid biomass capacity in tribal land $\mathrm{t}(\mathrm{MW})$

$\mathrm{AI}=$ Area of intersect (in this case, between resource and tribal land)

$\mathrm{P}=$ Bone dry tonne potential resource

$\mathrm{C}=$ Solid biomass conversion to energy $(1.1 \mathrm{MWh} /$ bone dry tonne $)$

CFbio $=$ Capacity factor for biopower

\section{Geothermal}

Two types of geothermal systems were included in this analysis: undiscovered hydrothermal and enhanced geothermal system (EGS). Undiscovered hydrothermal system estimates were derived from Williams et al. 2009. The estimates were generated using a logistical regression model of the western United States. The model determined favorability and estimated a power density, which was used to determine the potential capacity, expressed as:

$$
\text { Hydrothermcap }{ }_{t}=\sum_{i \in I_{t}} A_{i} \cdot P D_{i}
$$


where

$\mathrm{t}=$ Tribal land

Hydrothermcap $\mathrm{p}_{\mathrm{t}}=$ hydrothermal capacity in tribal land $t(\mathrm{MW})$

$\mathrm{i}=$ Distinct grid-cell

$\mathrm{I}_{\mathrm{t}}=$ Set of grid-cells that exist in tribal land $t$

$\mathrm{A}_{\mathrm{i}}=$ Square kilometers of available land in grid-cell $i$

$\mathrm{PD}_{\mathrm{i}}=$ Power density for grid-cell $i$

Undiscovered hydrothermal generation was estimated using:

$$
\text { Hydrothermgen }_{t}=\text { Hydrothermcap } t \cdot C F h t \cdot 8760 h r
$$

where

$\mathrm{t}=$ tribal land

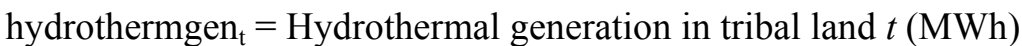

hydrothermcap $\mathrm{t}_{\mathrm{t}}=$ Hydrothermal capacity in tribal land $t(\mathrm{MW})$

CFht $=$ Capacity factor for hydrothermal

EGS technical potential estimates were calculated using temperature at depth data from the Southern Methodist University (SMU) Geothermal Laboratory. The data was first filtered to remove areas deemed unlikely for development (see Appendix 1). Next, the data was limited to areas intersecting tribal lands. Then, using the methodology described in Lopez et al. 2012 to determine optimal depth, capacity was estimated and can be expressed as:

$$
\operatorname{EGScap}_{t}=\sum_{i \in I_{t}} A_{i} \cdot P D_{i}
$$


where

$\mathrm{t}=$ Tribal land

EGScap $_{\mathrm{t}}=$ EGS capacity in tribal land $t(\mathrm{MW})$

$\mathrm{i}=$ Distinct grid-cell

$\mathrm{I}_{\mathrm{t}}=$ Set of grid-cells that exist in tribal land $t$

$\mathrm{A}_{\mathrm{i}}=$ Square kilometers of available land in grid-cell $i$

$\mathrm{PD}_{\mathrm{i}}=$ Power density for grid-cell $i$

Using the same optimal depth, technical potential generation was estimated and can be expressed as:

$$
\text { EGSgen }_{t}=\text { EGSCap }_{t} \cdot \text { CFegs } \cdot 8760 h r
$$

where

$\mathrm{t}=$ tribal land

EGSgen $_{\mathrm{t}}=$ EGS generation in tribal land $t(\mathrm{MWh})$

EGScap $_{\mathrm{t}}=$ EGS capacity in tribal land $t(\mathrm{MW})$

CFegs $=$ Capacity factor for EGS

\section{Hydropower}

Hydropower in this study is defined as low power $\left(<1 \mathrm{MWa}^{1}\right)$ or small hydro $(>=1 \mathrm{MWa}$ and $<=20$ MWa). Hydropower source point locations with potential average capacity were taken from Hall et al. 2006. The source points were a result of a feasibility study and development model; thus, no action was required on NREL's part to determine technical feasibility.

\footnotetext{
${ }^{1}$ Average megawatt capacity; assumes $50 \%$ capacity factor.
} 
To estimate technical potential capacity, the hydropower source points were intersected with tribal lands, summed by Tribe and doubled. The doubling backs out the assumed capacity factor in the average capacity. Technical potential capacity can be expressed as:

$$
\text { Hydrocap }_{t}=\sum_{j \in J_{t}} \frac{\text { Pcapa }_{j}}{\text { CFhydro }}
$$

where

$\mathrm{t}=$ Tribal land

Hydrocap $_{\mathrm{t}}=$ Hydropower capacity in tribal land $t$ (MW)

$\mathrm{Pcapa}_{\mathrm{j}}=$ Hydropower average capacity for source point $j$ (MWa)

$\mathrm{j}=$ Hydropower source point

$\mathrm{J}_{\mathrm{t}}=$ Set of hydropower source points in tribal land $t$

CFhydro $=$ Capacity factor for hydropower

Technical potential generation was estimated by maintaining the existing capacity factor in the average capacity and adding the time component, expressed as:

$$
\text { Hydrogen }_{t}=\sum_{j \in J_{t}} \text { Pcapa }_{j} \cdot 8760 h r
$$

where

$\mathrm{t}=$ Tribal land

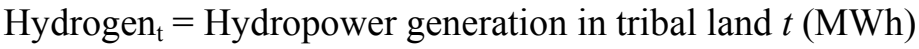

$\mathrm{Pcapa}_{\mathrm{j}}=$ Hydropower average capacity for source point $j(\mathrm{MWa})$

$\mathrm{j}=$ Hydropower source point

$\mathrm{J}_{\mathrm{t}}=$ Set of hydropower source points in tribal land $t$ 


\section{Concentrating Solar Power}

CSP is a utility-scale solar power plant in which the solar heat energy is collected in a central location. To get a general sense of CSP potential, CSP resource is analyzed. CSP resource is typically measured using direct normal irradiance (DNI) ${ }^{2}$ as kilowatt-hours $(\mathrm{kWh})$ per square meter per day $\left(\mathrm{kWh} / \mathrm{m}^{2} /\right.$ day $)$. In this analysis, we consider viable only areas with DNI greater than or equal to $5 \mathrm{kWh} / \mathrm{m}^{2} /$ day (Lopez et al.

2012).

Further reducing developable land was needed to ensure a more realistic potential. The first step was to remove areas with slope greater than or equal to 3\%. Next, areas with land-use/land-cover deemed unlikely for development were excluded (see Appendix). Last, areas were constrained to tribal lands, and a minimum contiguous area threshold of 1 square kilometer was imposed to ensure a utility-scale system.

With developable lands defined, a specific CSP system was defined and capacity and generation estimated. The system chosen was a trough, dry-cooled one with six hours of storage and a solar multiple of $2{ }^{3}$ The assumed system power density was 32.8 megawatts per kilometer squared (Lopez et al. 2012). Technical potential capacity was expressed as:

$$
\operatorname{CSPcap}_{t}=\sum_{i \in I_{t}} A_{i} \cdot P D
$$

where

$\mathrm{t}=$ Tribal land

$\mathrm{CSPcap}_{\mathrm{t}}=$ CSP capacity in tribal land $t(\mathrm{MW})$

$\mathrm{i}=$ Distinct grid-cell

$\mathrm{I}_{\mathrm{t}}=$ Set of grid-cells that exist in tribal land $t$

$\mathrm{A}_{\mathrm{i}}=$ Square kilometers of available land in grid-cell $i$

$\mathrm{PD}=$ Power density $\left(32 \mathrm{MW} / \mathrm{km}^{2}\right)$

To estimate generation potential, the DNI resource was divided into five classes. Capacity factors were taken from Lopez et al. 2012. Technical potential generation was then calculated and can be expressed as:

\footnotetext{
${ }^{2}$ The amount of solar radiation received per unit area by a surface that is always held perpendicular (or normal) to the rays that come in a straight line from the direction of the sun at its current position in the sky.

${ }^{3}$ The field aperture area expressed as a multiple of the aperture required to operate the power cycle at its design capacity.
} 


$$
\text { CSPgen }_{t}=\sum_{i \in I_{t}} A_{i} \cdot P D \cdot C F \operatorname{Csp}_{i} \cdot 8760 h r
$$

where

$\mathrm{t}=$ Tribal land

CSPgen $_{\mathrm{t}}=\mathrm{CSP}$ generation in tribal land $t(\mathrm{MWh})$

$\mathrm{i}=$ Distinct grid-cell

$\mathrm{I}_{\mathrm{t}}=$ Set of grid-cells that exist in tribal land $t$

$\mathrm{A}_{\mathrm{i}}=$ Square kilometers of available land in grid-cell $i$

$\mathrm{CFcsp}_{\mathrm{i}}=$ Capacity factor for CSP for grid-cell $i$

$\mathrm{PD}=$ Power density $\left(32 \mathrm{MW} / \mathrm{km}^{2}\right)$

\section{Solar PV}

The technical potential for solar utility-scale PV was first determined by eliminating areas deemed unlikely for development. These areas include those of environmental concern and national parks (a full list is included in Appendix 1). Note that the exclusions do not include potentially culturally sensitive areas as there is not currently a comprehensive dataset of those sites available. Next, the available land within each tribal boundary was separated into urban and rural classifications. This allows for a greater understanding of the geographic quality of PV potential (i.e., proximity to areas where the electricity might be used).

Urban available lands were constrained to eliminate impervious surfaces. This has the effect of removing roads, parking lots, and buildings, leaving only urban open space. The urban open spaces were further constrained to eliminate contiguous areas less than 18,000 square meters; this ensures the total system size is large enough to be considered utility scale. ${ }^{4}$

Rural available lands were constrained to eliminate areas less than 1 square kilometer. The area constraint reduces highly fragmented parcels.

The final step in calculating technical potential required a specific PV system. The PV system chosen was a 1 -axis tracking collector with the axis of rotation aligned north-south at $0^{\circ}$ tilt from the horizontal. Assuming a power density of $48 \mathrm{MW}$ per square kilometer (Lopez et al. 2012), the technical potential capacity was estimated and can be expressed as:

\footnotetext{
${ }^{4}$ Depending on the PV system, $18,000 \mathrm{~m}^{2}$ is roughly a 1-MW system.
} 


$$
\operatorname{PVcap}_{t}=\sum_{i \in I_{t}} A_{i} \cdot P D
$$

where

$\mathrm{t}=$ Tribal land

$\mathrm{PV} \mathrm{pap}_{\mathrm{t}}=\mathrm{PV}$ capacity in tribal land $t(\mathrm{MW})$

$\mathrm{i}=$ Distinct grid-cell

$\mathrm{I}_{\mathrm{t}}=$ Set of grid-cells that exist in tribal land $t$

$\mathrm{A}_{\mathrm{i}}=$ Square kilometers of available land in grid-cell $i$

$\mathrm{PD}=$ Power density $\left(48 \mathrm{MW} / \mathrm{km}^{2}\right)$

To determine technical potential generation, capacity factors were estimated. State-level capacity factors were taken from Lopez et al. 2012. Technical potential generation can be expressed as:

$$
\operatorname{PVgen}_{t}=\sum_{i \in I_{t}} A_{i} \cdot P D \cdot C F p v_{i} \cdot 8760 h r
$$

where

$\mathrm{t}=$ Tribal land

$\mathrm{PVgen}_{\mathrm{t}}=\mathrm{PV}$ generation in tribal land $\mathrm{t}(\mathrm{MWh})$

$\mathrm{i}=$ Distinct grid-cell

$\mathrm{I}_{\mathrm{t}}=$ Set of grid-cells that exist in tribal land $t$

$\mathrm{CFpv}=$ Capacity factor for PV for grid-cell $i$ 


\section{Wind}

Wind was analyzed at 80 meters (m) above the earth's surface. Only windy areas greater than or equal to an annual average gross capacity factor ${ }^{5}$ of $30 \%$ were included in the analysis. The gross capacity factors used in the analysis were developed by AWS Truepower; they represent typical utility-scale wind turbine power curves.

The resource areas were filtered to remove areas deemed unlikely for development, including: national parks, federally protected lands, and water features. For a full list of exclusions, see Appendix 1.

Technical potential capacity for wind was estimated assuming $5 \mathrm{MW} / \mathrm{km}^{2}$ (Lopez et al. 2012) and can be expressed as:

$$
\text { Windcap }_{t}=\sum_{i \in I_{t}} A_{i} \cdot P D
$$

where

$\mathrm{t}=$ Tribal land

Windcap $_{\mathrm{t}}=$ Wind capacity in tribal land $t(\mathrm{MW})$

$\mathrm{i}=$ Distinct grid-cell

$\mathrm{I}_{\mathrm{t}}=$ Set of grid-cells that exist in tribal land $t$

$\mathrm{A}_{\mathrm{i}}=$ Square kilometers of available land in grid-cell $i$

$\mathrm{PD}=$ Power density $\left(5 \mathrm{MW} / \mathrm{km}^{2}\right)$

Technical potential for wind generation was estimated assuming 15\% energy losses (Lopez et al. 2012) and can be expressed as:

$$
\text { Windgen }_{t}=\sum_{i \in I_{t}} A_{i} \cdot P D \cdot C \text { wind }_{i} \cdot 8760 \mathrm{hr} \cdot \text { loss }
$$

\footnotetext{
${ }^{5}$ Gross capacity factor does not include plant downtime, parasitic power, or other factors that would be included to reduce output to the "net" capacity factor. For more information on capacity factors, see http://www.eia.gov/tools/faqs/faq.cfm?id=187\&t=3.
} 


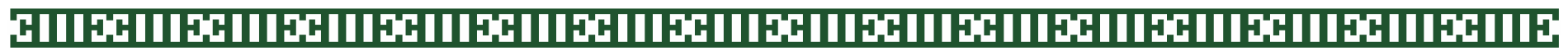

where

$\mathrm{t}=$ Tribal land

Windgen $_{\mathrm{t}}=$ Wind generation on tribal land $t(\mathrm{MWh})$

$\mathrm{i}=$ Distinct grid-cell

$\mathrm{I}_{\mathrm{t}}=$ Set of grid-cells that exist in tribal land $t$

$\mathrm{CFwind}_{\mathrm{i}}=$ Capacity factor for wind for grid-cell $i$

loss $=15 \%$ reduction from gross to net generation 


\section{Results}

The methodology results in an understanding of the technical potential for renewable energy on tribal lands by resource. It provides a starting point for understanding where Tribes could prioritize the development of renewable energy resources, either for community-scale on-tribal-land use or for revenuegenerating electricity sales.

Findings indicate that while tribal lands comprise $2 \%$ of U.S. lands, technical potential on tribal lands comprises $4.8 \%$ of the total national U.S. technical capacity potential for renewable energy and $6 \%$ of the total generation, varying by resource (see Table 4-1). Solar photovoltaics (both urban and rural), concentrated solar power, and wind have the largest technical potential of the renewable resources. Geographically, tribal lands in the Southwest have the greatest percentage of the potential. The following subsections provide more detail on the technical potential by renewable energy resource and tribal land. 
Table 4-1. Summary of Tribal Technical Potential by Capacity and Generation

\begin{tabular}{|c|c|c|c|c|c|c|}
\hline Technology & $\begin{array}{l}\text { Tribal } \\
\text { Capacity } \\
\text { Potentiala } \\
\text { (MW) }\end{array}$ & $\begin{array}{l}\text { National } \\
\text { Capacity } \\
\text { Potentiala } \\
(\mathrm{MW})\end{array}$ & $\begin{array}{l}\text { Tribal } \\
\text { Generation } \\
\text { Potentiala } \\
\text { (MWh) }\end{array}$ & $\begin{array}{l}\text { National } \\
\text { Generation } \\
\text { Potentiala (MWh) }\end{array}$ & $\begin{array}{l}\% \text { of } \\
\text { National } \\
\text { Capacity }\end{array}$ & $\begin{array}{l}\% \text { of } \\
\text { National } \\
\text { Generation }\end{array}$ \\
\hline $\begin{array}{l}\text { Solar PV } \\
\text { (Utility-Scale, } \\
\text { Rural) }\end{array}$ & $6,888,339$ & $152,973,829$ & $14,322,522,713$ & $280,613,216,903$ & $4.5 \%$ & $5.1 \%$ \\
\hline $\begin{array}{l}\text { Solar PV } \\
\text { (Utility-Scale, } \\
\text { Urban) }\end{array}$ & 8,199 & $1,217,699$ & $17,578,618$ & $2,231,693,746$ & $0.7 \%$ & $0.8 \%$ \\
\hline Solar CSP & $1,818,185$ & $38,066,401$ & $6,139,851,743$ & $116,146,244,587$ & $4.8 \%$ & $5.3 \%$ \\
\hline $\begin{array}{l}\text { Wind ( } 80 \mathrm{~m} \\
\text { height, >=30\% } \\
\text { GCF) }\end{array}$ & $\begin{array}{r}374,50 \\
5\end{array}$ & $10,954,759$ & $1,146,044,229$ & $32,784,004,656$ & $3.4 \%$ & $3.5 \%$ \\
\hline $\begin{array}{l}\text { Geothermal } \\
\text { (EGS) }\end{array}$ & $\begin{array}{r}763,25 \\
2 \\
\end{array}$ & $3,975,735$ & $6,017,487,000$ & $31,344,696,024$ & $19.2 \%$ & $19.2 \%$ \\
\hline $\begin{array}{l}\text { Geothermal } \\
\text { (Hydrothermal) }\end{array}$ & 641 & 30,033 & $5,050,724$ & $236,780,000$ & $2.1 \%$ & $2.1 \%$ \\
\hline $\begin{array}{l}\text { Biomass } \\
\text { (Solid) }\end{array}$ & 551 & 50,707 & $4,340,642$ & $399,774,091$ & $1.1 \%$ & $1.1 \%$ \\
\hline $\begin{array}{l}\text { Biomass } \\
\text { (Gaseous) }\end{array}$ & 85 & 11,232 & 673,465 & $88,551,445$ & $0.8 \%$ & $0.8 \%$ \\
\hline Hydropower & 1,687 & 60,000 & $7,390,196$ & $258,953,000$ & $2.8 \%$ & $2.9 \%$ \\
\hline Totalb & $9,855,444$ & $207,340,394$ & $27,660,939,330$ & $464,103,914,451$ & $4.8 \%$ & $6.0 \%$ \\
\hline
\end{tabular}

${ }^{a}$ Lopez, A. et al. (2012). U.S. Renewable Energy Technical Potentials: A GIS-Based Analysis. NREL/TP-6A20-51946. Golden, CO: National Renewable Energy Laboratory.

${ }^{\mathrm{b}}$ Technical potential calculated for each technology individually and does not account for overlap (i.e., the same land area may be identified with potential for wind and solar, and would be counted twice in the total). Some technologies may be compatible with mutual development. 


\section{Biomass}

The total technical potential for electricity generation from solid biomass on tribal lands is about 399 million MWh, or about $1.1 \%$ of the total U.S. technical potential. The top three tribal lands in terms of potential generation are Nez Perce (336,000 MWh), Lake Traverse (Sisseton) (300,000 MWh), and Yakama (274,000 MWh). The top 25 tribal lands by technical potential for biopower from solid (Table 42) and gaseous (Table 4-3) biomass resources are below. An alphabetical list of all technical potentials by tribal lands is in Appendix 2. Developable potential of biomass resources is often limited by the market costs of transporting the fuel.

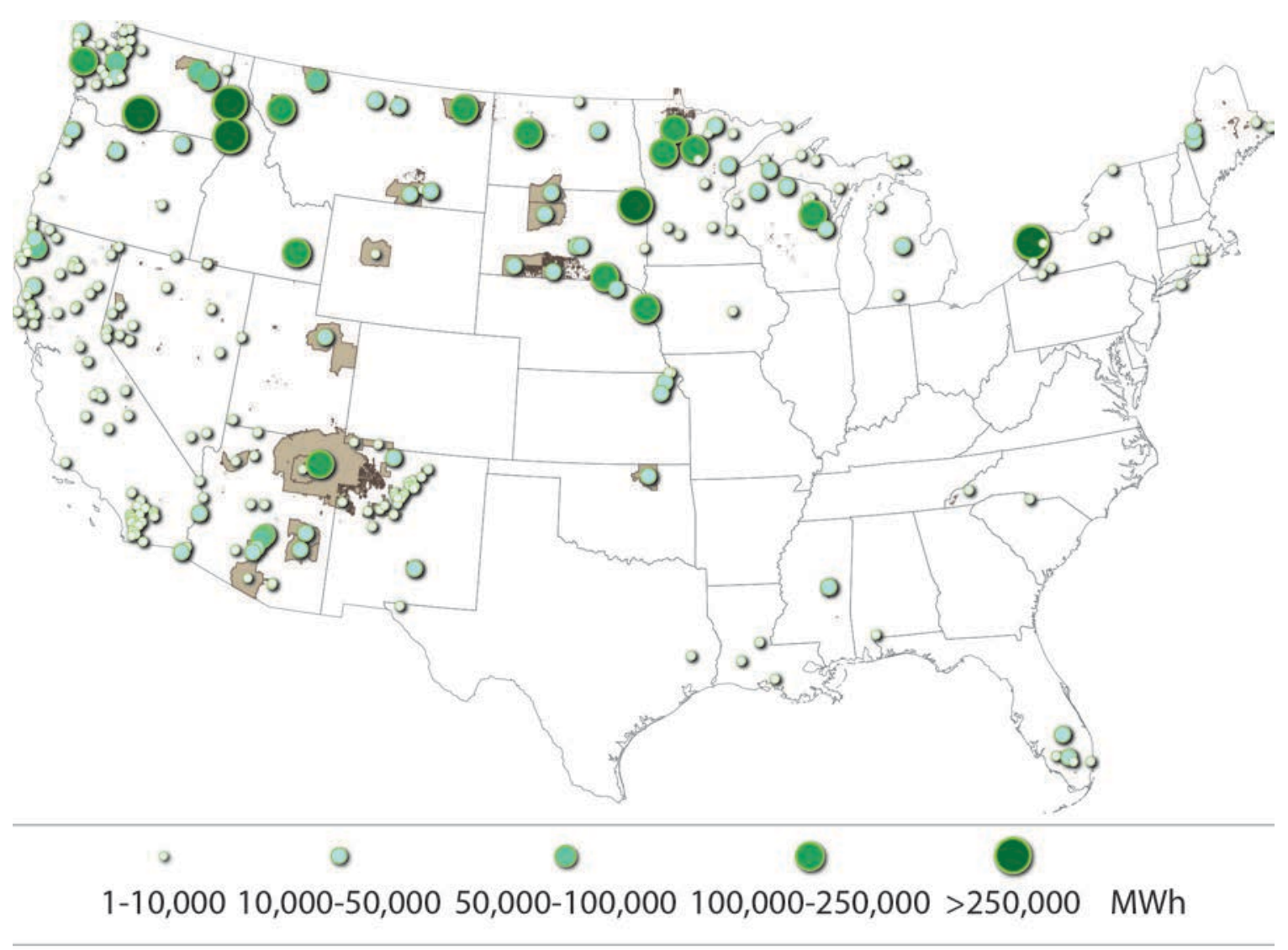

Figure 2. Tribal lands biomass generation potential 


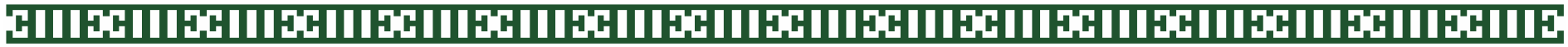

Table 4-2. Top 25 Tribal Lands by Technical Potential for Biopower Generation from Solid Residues

\begin{tabular}{|c|c|c|c|}
\hline Tribal Land & State & $\begin{array}{l}\text { Biopower from } \\
\text { Solid Residues }{ }^{a} \\
\text { (MWh) }\end{array}$ & $\begin{array}{l}\text { Biopower from } \\
\text { Solid Residues } \\
(\mathrm{MW})\end{array}$ \\
\hline Nez Perce & ID & 336,781 & 43 \\
\hline Lake Traverse (Sisseton) & $\mathrm{SD}, \mathrm{MN}, \mathrm{ND}$ & 300,466 & 38 \\
\hline Yakama & WA & 274,750 & 35 \\
\hline Coeur d'Alene & WA,ID & 264,737 & 34 \\
\hline Menominee & WI & 246,145 & 31 \\
\hline Quinault & WA & 161,549 & 20 \\
\hline Fort Peck & MT & 159,234 & 20 \\
\hline Leech Lake & $\mathrm{MN}$ & 158,657 & 20 \\
\hline Omaha & IA, NE & 143,838 & 18 \\
\hline White Earth & $\mathrm{MN}$ & 138,785 & 18 \\
\hline Red Lake & $\mathrm{MN}$ & 124,764 & 16 \\
\hline Flathead & MT & 123,572 & 16 \\
\hline Yankton & NE, SD & 114,257 & 14 \\
\hline Fort Berthold & ND & 109,151 & 14 \\
\hline Navajo & NM, UT, AZ, CO & 103,018 & 13 \\
\hline Fort Hall & ID & 101,896 & 13 \\
\hline Blackfeet & MT & 87,202 & 11 \\
\hline Winnebago & IA, NE & 76,709 & 10 \\
\hline Ho-Chunk & WI & 68,939 & 9 \\
\hline Spokane & WA & 66,932 & 8 \\
\hline Colville & WA & 59,616 & 8 \\
\hline Hoopa Valley & $\mathrm{CA}$ & 55,748 & 7 \\
\hline Devils Lake Sioux & ND & 46,079 & 6 \\
\hline Crow & WY, MT & 43,001 & 5 \\
\hline Fond du Lac & $\mathrm{MN}$ & 41,847 & 5 \\
\hline
\end{tabular}

${ }^{a}$ Solid residues are represented by forest, crop, primary mill, and urban wood residues. Generation estimated assuming 1.1 $\mathrm{MWh} /$ bone dry tonne of residue. 


\section{Table 4-3. Top 25 Tribal Lands by Technical Potential for Biopower Generation from Gaseous Residues}

\begin{tabular}{|c|c|c|c|}
\hline Tribal Land & State & $\begin{array}{l}\text { Biopower from } \\
\text { Gaseous } \\
\text { Residuesa } \\
\text { (MWh) }\end{array}$ & $\begin{array}{l}\text { Biopower from } \\
\text { Gaseous } \\
\text { Residues } \\
(\mathrm{MW})\end{array}$ \\
\hline Tuscarora & NY & 440,925 & 56 \\
\hline Yawapa Apache & $A Z$ & 74,323 & 9 \\
\hline Port Madison & WA & 61,835 & 8 \\
\hline Salt River & $\mathrm{AZ}$ & 59,395 & 8 \\
\hline Cocopah & $\mathrm{AZ}, \mathrm{CA}$ & 25,403 & 3 \\
\hline Navajo & NM, UT, AZ, CO & 1,755 & 0 \\
\hline Lone Pine Rancheria & $\mathrm{CA}$ & 888 & 0 \\
\hline Osage & $\mathrm{OK}$ & 659 & 0 \\
\hline Gila River & $\mathrm{AZ}$ & 459 & 0 \\
\hline Puyallup & WA & 427 & 0 \\
\hline Uintah and Ouray & UT & 335 & 0 \\
\hline Yakama & WA & 329 & 0 \\
\hline Isabella (Sag Chip) & $\mathrm{MI}$ & 320 & 0 \\
\hline Tohono O'odham & $\mathrm{AZ}$ & 296 & 0 \\
\hline San Xavier (TON) & $\mathrm{AZ}$ & 293 & 0 \\
\hline Agua Caliente & $\mathrm{CA}$ & 268 & 0 \\
\hline Flathead & MT & 262 & 0 \\
\hline Oneida (West) & WI & 232 & 0 \\
\hline Crow & WY, MT & 229 & 0 \\
\hline Fort Hall & ID & 210 & 0 \\
\hline Wind River & WY & 183 & 0 \\
\hline White Mountain & $\mathrm{AZ}$ & 182 & 0 \\
\hline Isleta Pueblo & NM & 169 & 0 \\
\hline Tulalip & WA & 164 & 0 \\
\hline Southern Ute & $\mathrm{NM}, \mathrm{CO}$ & 144 & 0 \\
\hline
\end{tabular}

${ }^{\mathrm{a}}$ Gaseous residues are represented by landfill and domestic wastewater residues. Generation estimated assuming $4.7 \mathrm{MWh} /$ tonne of $\mathrm{CH} 4$ produced by the residues. 


\section{Geothermal}

The total technical potential on tribal lands for hydrothermal geothermal resource capacity is about 236 million MWh, or about $2.1 \%$ of the total U.S. technical potential. The top three tribal lands in terms of potential generation are Navajo (597,000 MWh), Tohono O'odham (510,000 MWh), and Warm Springs (405,000 MWh). Table 4-4 lists the top 25 tribal lands in terms of the technical potential of hydrothermal generation with enhanced geothermal systems (EGS, a less commercially viable geothermal option) for reference. A full list of technical potential by tribal land is listed in Appendix 2. Geothermal resources are widely distributed across tribal lands, with 196 distinct lands having technical potential.

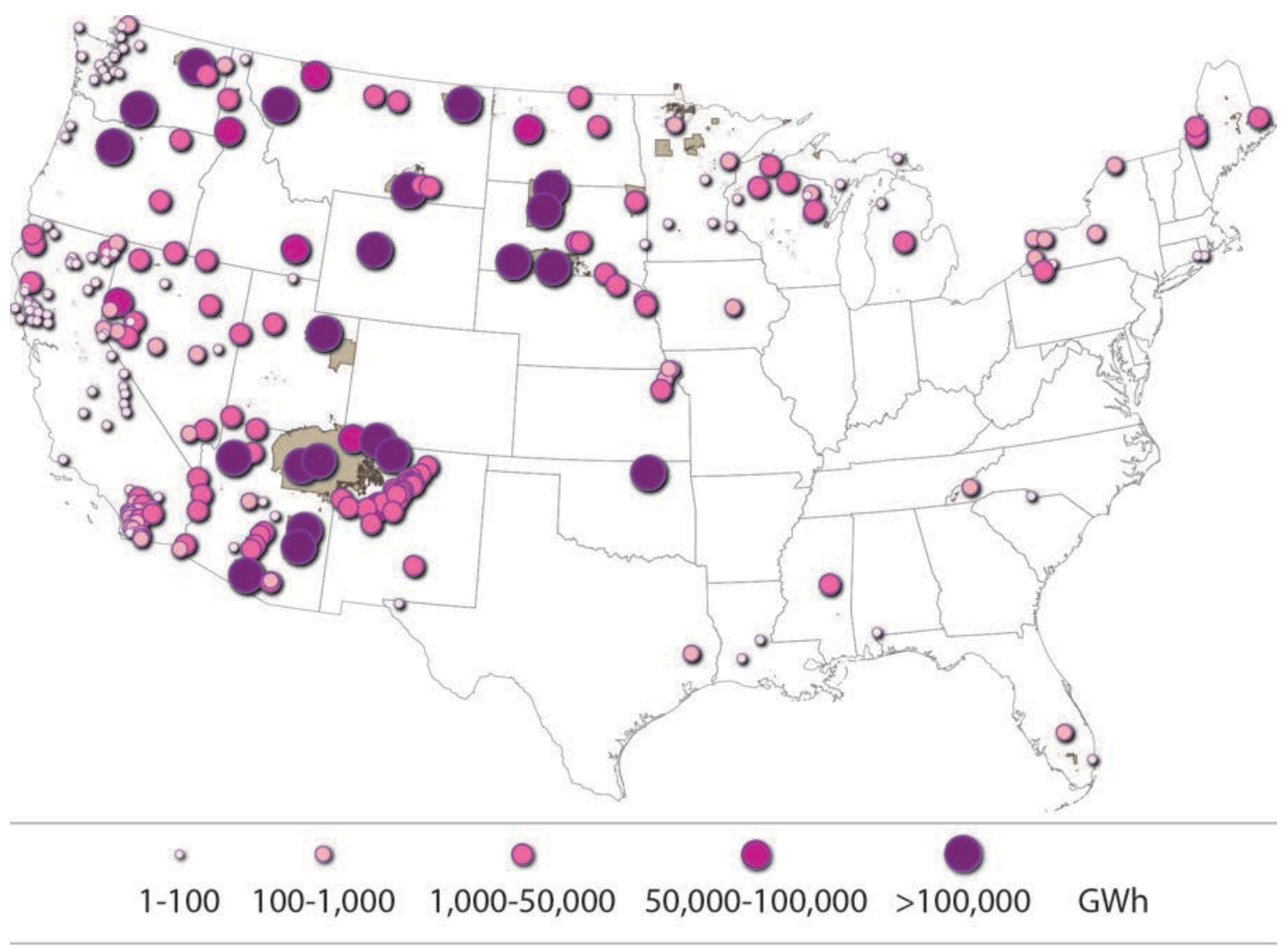

Figure 3. Tribal lands geothermal (EGS and hydrothermal) generation potential 

Table 4-4. Top 25 Tribal Lands by Technical Potential for Hydrothermal Geothermal
Generation

\begin{tabular}{|c|c|c|c|c|c|}
\hline Name & State & $\begin{array}{l}\text { Unidentified } \\
\text { Hydrothermal } \\
\text { Potential } \\
\text { Annual } \\
\text { Generation } \\
\text { (MWh) }\end{array}$ & $\begin{array}{l}\text { Unidentified } \\
\text { Hydrothermal } \\
\text { Potential } \\
\text { Installed } \\
\text { Capacity } \\
\text { (MW) }\end{array}$ & $\begin{array}{l}\text { Enhanced } \\
\text { Geothermal } \\
\text { Systems } \\
\text { Potential } \\
\text { Annual } \\
\text { Generation } \\
\text { (MWh) }\end{array}$ & $\begin{array}{l}\text { Enhanced } \\
\text { Geothermal } \\
\text { Systems } \\
\text { Potential } \\
\text { Installed } \\
\text { Capacity (MW) }\end{array}$ \\
\hline Navajo & $\begin{array}{r}\mathrm{NM}, \mathrm{UT}, \mathrm{AZ}, \\
\mathrm{CO}\end{array}$ & 597,545 & 76 & $1,263,774,000$ & 160,296 \\
\hline $\begin{array}{l}\text { Tohono } \\
\text { O'odham }\end{array}$ & $A Z$ & 510,243 & 65 & $323,796,000$ & 41,070 \\
\hline Warm Springs & OR & 405,953 & 51 & $102,311,000$ & 12,977 \\
\hline Pyramid Lake & $\mathrm{NV}$ & 324,409 & 41 & $58,397,000$ & 7,407 \\
\hline Walker River & NV & 246,481 & 31 & $41,959,000$ & 5,322 \\
\hline Hualapai & $A Z$ & 210,076 & 27 & $121,721,000$ & 15,439 \\
\hline Southern Ute & $\mathrm{NM}, \mathrm{CO}$ & 188,245 & 24 & $121,248,000$ & 15,379 \\
\hline San Carlos & $\mathrm{AZ}$ & 179,374 & 23 & $195,137,000$ & 24,751 \\
\hline Fort Hall & ID & 179,275 & 23 & $78,603,000$ & 9,970 \\
\hline Duck Valley & $\mathrm{NV}, \mathrm{ID}$ & 164,004 & 21 & $40,642,000$ & 5,155 \\
\hline Yakama & WA & 155,549 & 20 & $127,957,000$ & 16,230 \\
\hline Flathead & MT & 151,999 & 19 & $122,383,000$ & 15,523 \\
\hline $\begin{array}{l}\text { Jicarilla } \\
\text { Apache }\end{array}$ & $\mathrm{NM}, \mathrm{CO}$ & 143,397 & 18 & $112,481,000$ & 14,267 \\
\hline Fort Peck & $\mathrm{MT}$ & 120,159 & 15 & $216,203,000$ & 27,423 \\
\hline $\begin{array}{l}\text { White } \\
\text { Mountain } \\
\end{array}$ & $\mathrm{AZ}$ & 119,240 & 15 & $150,687,000$ & 19,113 \\
\hline $\begin{array}{l}\text { Lake Traverse } \\
\text { (Sisseton) }\end{array}$ & $\begin{array}{r}\text { SD, MN, } \\
\text { ND }\end{array}$ & 88,772 & 11 & $35,762,000$ & 4,536 \\
\hline $\begin{array}{l}\text { Uintah and } \\
\text { Ouray }\end{array}$ & UT & 78,807 & 10 & $347,054,000$ & 44,020 \\
\hline Colville & WA & 70,390 & 9 & $127,342,000$ & 16,152 \\
\hline Blackfeet & MT & 60,031 & 8 & $95,089,000$ & 12,061 \\
\hline Nez Perce & ID & 51,827 & 7 & $72,943,000$ & 9,252 \\
\hline Wind River & WY & 47,999 & 6 & $174,985,000$ & 22,195 \\
\hline Taos Pueblo & NM & 46,205 & 6 & $11,124,000$ & 1,411 \\
\hline Zuni Pueblo & $\mathrm{NM}, \mathrm{AZ}$ & 44,632 & 6 & $42,857,000$ & 5,436 \\
\hline Isleta Pueblo & NM & 44,203 & 6 & $23,479,000$ & 2,978 \\
\hline Goshute & NV, UT & 44,152 & 6 & $12,898,000$ & 1,636 \\
\hline
\end{tabular}




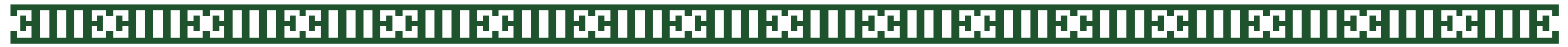

\section{Hydropower}

The total technical potential on tribal lands for generation from hydropower resource is about 13 million MWh, or about $5.1 \%$ of the total U.S. technical potential. The top three tribal lands in terms of potential generation are Nez Perce (2.6 million MWh), Flathead (1.5 million MWh), and Yakama (1.2 million MWh). A full list of technical potential by tribal land is listed in Appendix 2.

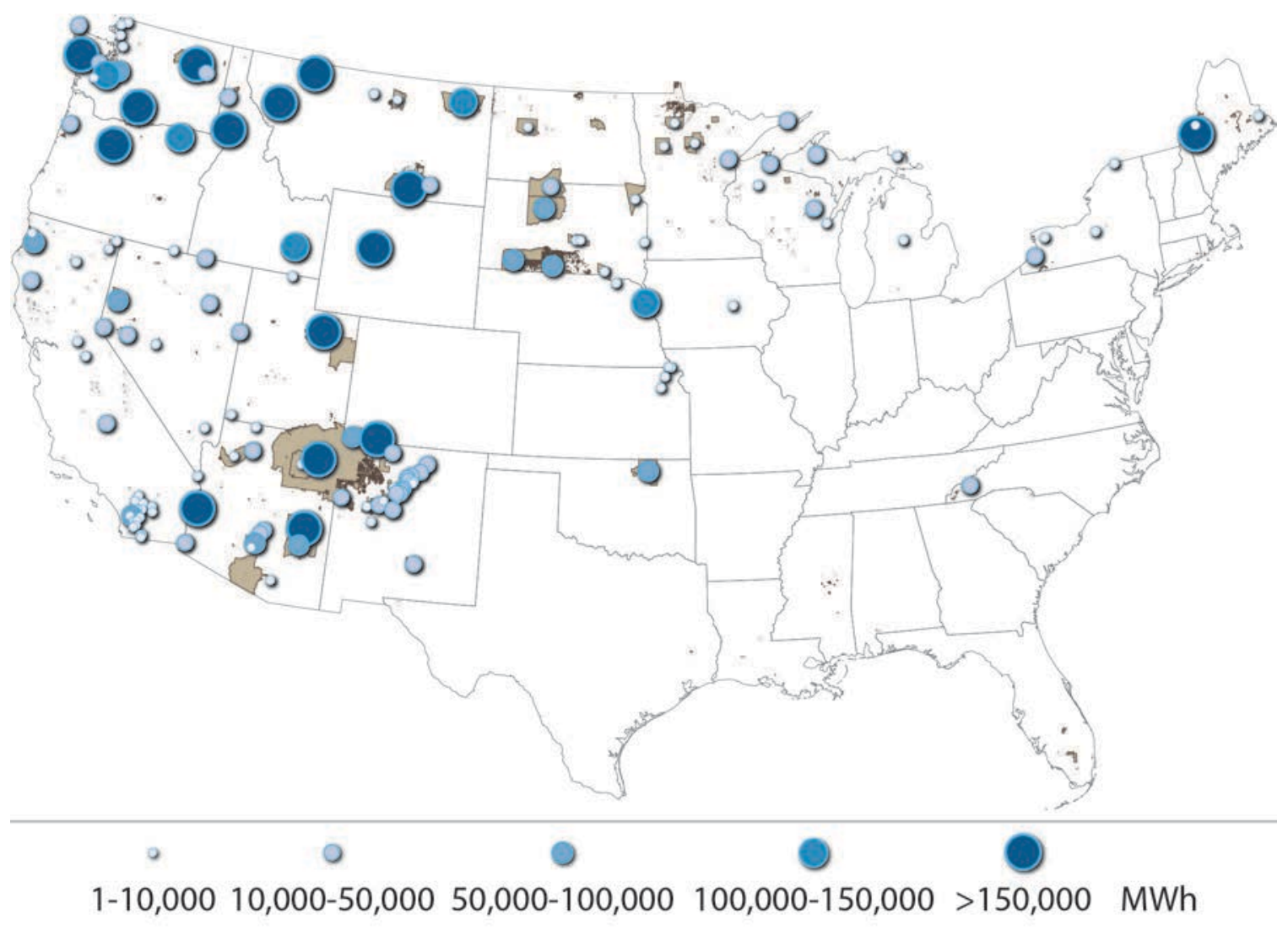

Figure 4. Tribal lands hydropower generation potential 
Table 4-5. Top 25 Tribal Lands by Technical Potential for Hydropower Generation

\begin{tabular}{|c|c|c|c|}
\hline Tribal Land & State & $\begin{array}{l}\text { Hydropower } \\
\text { Generation } \\
\text { Potential (MWh) }\end{array}$ & $\begin{array}{l}\text { Hydropower } \\
\text { Capacity } \\
\text { Potential (MW) }\end{array}$ \\
\hline Nez Perce & ID & $1,445,260$ & 330 \\
\hline Flathead & MT & 816,341 & 186 \\
\hline Yakama & WA & 669,640 & 153 \\
\hline Blackfeet & MT & 445,893 & 102 \\
\hline Uintah and Ouray & UT & 442,276 & 101 \\
\hline Navajo & $\mathrm{NM}, \mathrm{UT}, \mathrm{AZ}, \mathrm{CO}$ & 369,000 & 84 \\
\hline Wind River & WY & 350,640 & 80 \\
\hline Quinault & WA & 339,978 & 78 \\
\hline Colville & WA & 247,936 & 57 \\
\hline Southern Ute & $\mathrm{NM}, \mathrm{CO}$ & 243,721 & 56 \\
\hline Penobscot & $\mathrm{ME}$ & 189,260 & 43 \\
\hline Warm Springs & OR & 130,737 & 30 \\
\hline White Mountain & $\mathrm{AZ}$ & 115,435 & 26 \\
\hline Colorado River & $A Z, C A$ & 106,505 & 24 \\
\hline Crow & WY, MT & 89,049 & 20 \\
\hline Fort Hall & ID & 70,593 & 16 \\
\hline Omaha & $\mathrm{IA}, \mathrm{NE}$ & 61,961 & 14 \\
\hline Fort Peck & MT & 57,645 & 13 \\
\hline Nisqually & WA & 57,594 & 13 \\
\hline Umatilla & OR & 57,403 & 13 \\
\hline San Carlos & $A Z$ & 49,442 & 11 \\
\hline Winnebago & $\mathrm{IA}, \mathrm{NE}$ & 48,821 & 11 \\
\hline Gila River & $A Z$ & 47,987 & 11 \\
\hline Cheyenne River & SD & 47,065 & 11 \\
\hline Muckleshoot & WA & 46,137 & 11 \\
\hline
\end{tabular}




\section{Concentrated Solar Power}

The total technical potential on tribal lands for electricity generation from utility-scale rural solar resource is about 6 billion MWh, or $5.3 \%$ of total U.S. generation potential. The top tribal lands in terms of potential generation are Navajo (3 billion MWh), Tohono O'odham (950 million MWh), and Hopi (300 million MWh). Developable potential of CSP is often limited to utility scale, and by transmission availability and access. A full list of technical potential by tribal land is listed in Appendix 2.

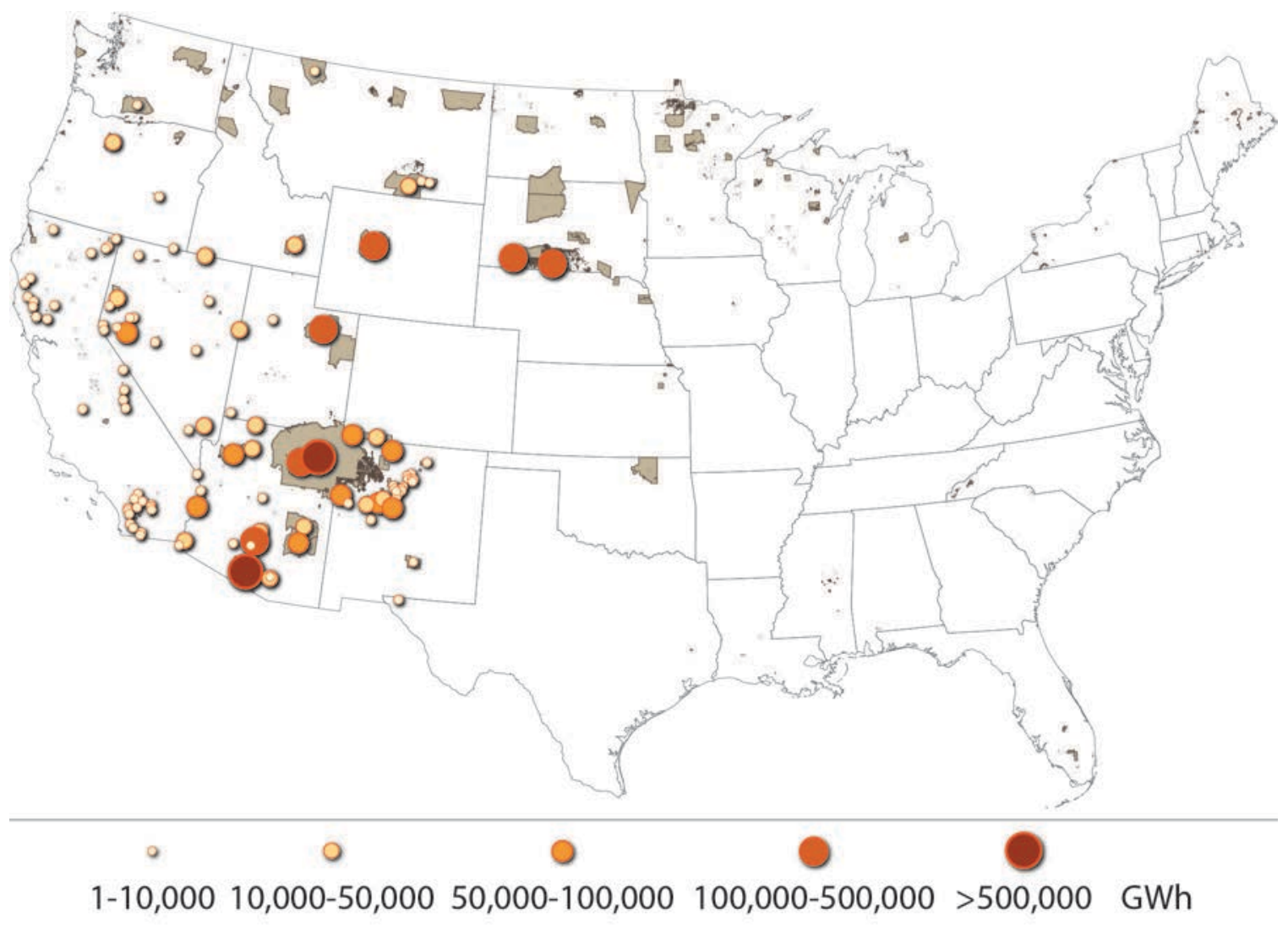

Figure 5. Tribal lands CSP generation potential 
Table 4-6. Top 25 Tribal Lands by Technical Potential for CSP Generation

\begin{tabular}{|c|c|c|c|c|}
\hline Tribal Land & State & $\begin{array}{l}\text { Concentrating } \\
\text { Solar Power } \\
\text { Potential } \\
\text { Annual } \\
\text { Generation } \\
\text { (MWh) }\end{array}$ & $\begin{array}{l}\text { Concentrating } \\
\text { Solar Power } \\
\text { Potential } \\
\text { Installed } \\
\text { Capacity } \\
\text { (MW) }\end{array}$ & $\begin{array}{l}\text { Concentrating } \\
\text { Solar Power } \\
\text { Available } \\
\text { Land }\left(\mathrm{km}^{2}\right)\end{array}$ \\
\hline Navajo & NM, UT, AZ, CO & $2,872,729,112$ & 830,414 & 25,950 \\
\hline Tohono O'odham & $\mathrm{AZ}$ & $950,059,233$ & 259,526 & 8,110 \\
\hline Hopi & $\mathrm{AZ}$ & $332,743,795$ & 95,030 & 2,970 \\
\hline Uintah and Ouray & UT & $196,030,481$ & 70,663 & 2,208 \\
\hline Pine Ridge & NE, SD & $193,254,076$ & 69,913 & 2,185 \\
\hline Wind River & WY & $172,102,126$ & 62,252 & 1,945 \\
\hline Rosebud & NE, SD & $125,329,342$ & 45,340 & 1,417 \\
\hline Gila River & $\mathrm{AZ}$ & $123,184,942$ & 35,754 & 1,117 \\
\hline Laguna Pueblo & NM & $91,734,396$ & 26,629 & 832 \\
\hline Colorado River & $\mathrm{AZ}, \mathrm{CA}$ & $87,227,378$ & 24,292 & 759 \\
\hline San Carlos & $\mathrm{AZ}$ & $87,046,169$ & 24,426 & 763 \\
\hline Hualapai & $\mathrm{AZ}$ & $68,215,389$ & 18,755 & 586 \\
\hline Zuni Pueblo & $\mathrm{NM}, \mathrm{AZ}$ & $60,942,972$ & 17,691 & 553 \\
\hline Jicarilla Apache & $\mathrm{NM}, \mathrm{CO}$ & $59,723,631$ & 17,337 & 542 \\
\hline Walker River & NV & $57,127,439$ & 16,583 & 518 \\
\hline Isleta Pueblo & NM & $54,658,370$ & 15,867 & 496 \\
\hline Ute Mountain & NM, UT, CO & $53,851,937$ & 15,633 & 489 \\
\hline Acoma Pueblo & NM & $47,628,883$ & 13,826 & 432 \\
\hline Duck Valley & NV,ID & $41,129,330$ & 14,879 & 465 \\
\hline Southern Ute & $\mathrm{NM}, \mathrm{CO}$ & $40,693,628$ & 11,813 & 369 \\
\hline Fort Hall & ID & $36,419,526$ & 13,175 & 412 \\
\hline White Mountain & $A Z$ & $30,465,149$ & 8,844 & 276 \\
\hline Pyramid Lake & NV & $29,464,482$ & 9,905 & 310 \\
\hline Crow & WY, MT & $28,153,272$ & 10,185 & 318 \\
\hline Moapa Band River & NV & $24,779,403$ & 6,672 & 208 \\
\hline
\end{tabular}




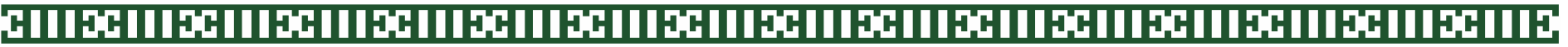

\section{Solar PV: Urban Utility Scale}

The total technical potential on tribal lands for generation from utility-scale solar resources on urban land is about 15 million MWh, or about $0.7 \%$ of the total U.S. technical potential. The top four tribal lands in terms of potential generation are Navajo (2 million MWh), Zuni Pueblo (1 million MWh), and San Juan Pueblo (1 million MWh). A full list of technical potential by tribal land is listed in Appendix 2.

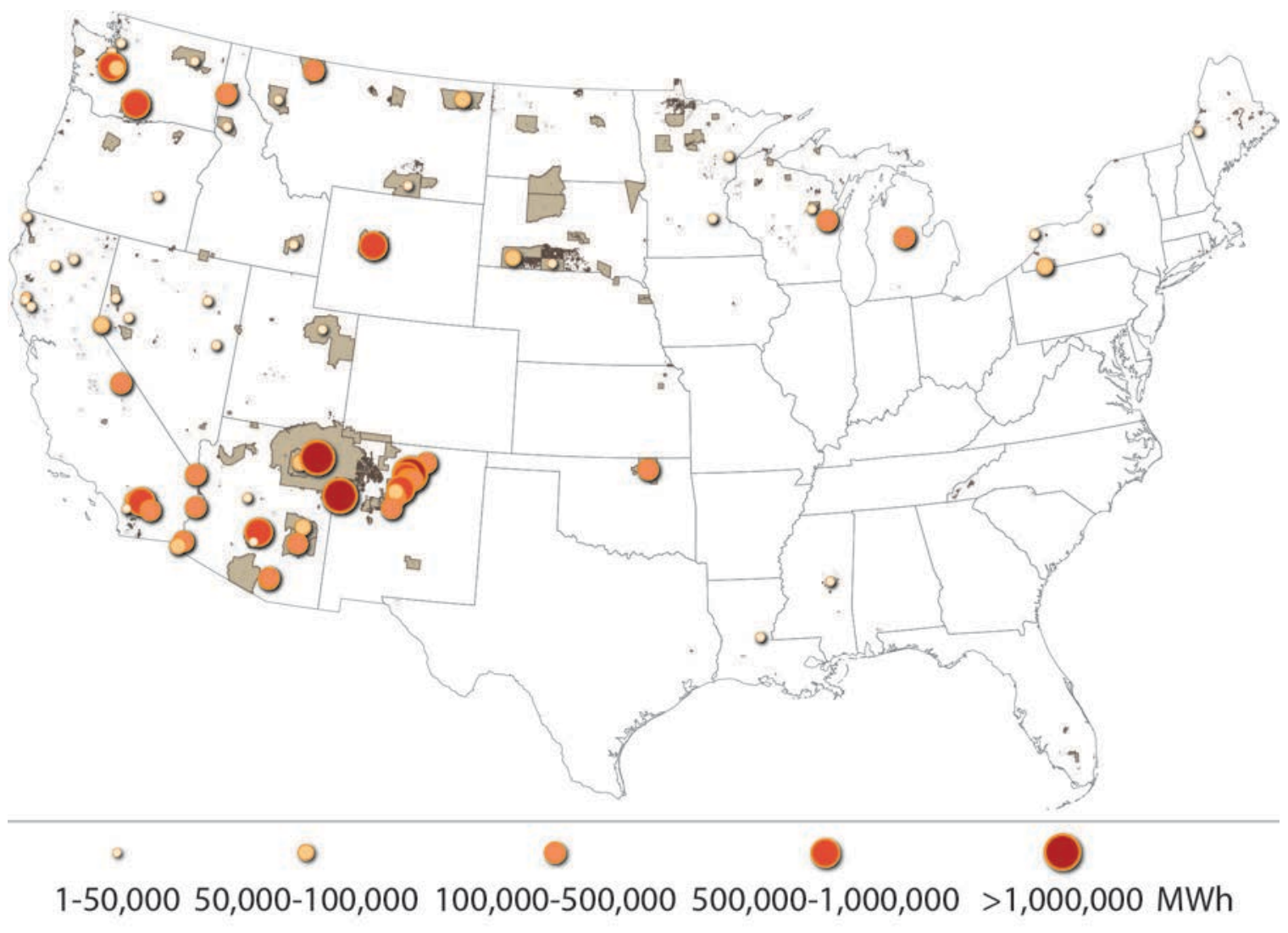

Figure 6. Tribal lands PV utility-scale urban generation potential 


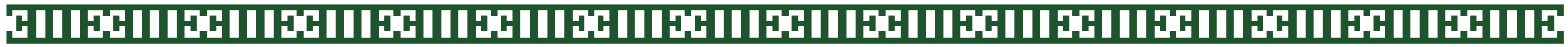

\section{Table 4-7. Top 25 Tribal Lands by Technical Potential for Urban Utility-Scale PV Generation}

\begin{tabular}{|c|c|c|c|c|}
\hline Tribal Land & State & $\begin{array}{l}\text { Urban Utility } \\
\text { PV Power } \\
\text { Potential } \\
\text { Annual } \\
\text { Generation } \\
\text { (MWh) }\end{array}$ & $\begin{array}{l}\text { Urban Utility } \\
\text { PV Potential } \\
\text { Installed } \\
\text { Capacity } \\
\text { (MW) }\end{array}$ & $\begin{array}{l}\text { Urban Utility } \\
\text { PV Available } \\
\text { Land }\left(\mathrm{km}^{2}\right)\end{array}$ \\
\hline Navajo & NM, UT, AZ, CO & $2,925,921$ & 1,269 & 26 \\
\hline Zuni Pueblo & $\mathrm{NM}, \mathrm{AZ}$ & $1,176,908$ & 511 & 11 \\
\hline San Juan Pueblo & NM & $1,104,495$ & 480 & 10 \\
\hline Santa Clara Pueblo & NM & $1,017,361$ & 442 & 9 \\
\hline Yakama & WA & 985,616 & 565 & 12 \\
\hline Salt River & $\mathrm{AZ}$ & 932,717 & 405 & 8 \\
\hline Agua Caliente & $\mathrm{CA}$ & 798,375 & 362 & 8 \\
\hline Puyallup & WA & 700,760 & 402 & 8 \\
\hline Wind River & WY & 691,383 & 345 & 7 \\
\hline Santo Domingo Pueblo & NM & 661,364 & 287 & 6 \\
\hline Osage & $\mathrm{OK}$ & 562,649 & 288 & 6 \\
\hline Pojoaque Pueblo & NM & 431,394 & 187 & 4 \\
\hline San Xavier (TON) & $A Z$ & 415,559 & 180 & 4 \\
\hline Taos Pueblo & NM & 399,066 & 173 & 4 \\
\hline Oneida (West) & WI & 372,008 & 237 & 5 \\
\hline Fort Mojave & $\mathrm{NV}, \mathrm{AZ}, \mathrm{CA}$ & 340,340 & 150 & 3 \\
\hline Sandia Pueblo & NM & 320,984 & 139 & 3 \\
\hline Torres-Martinez & $\mathrm{CA}$ & 319,770 & 145 & 3 \\
\hline San Carlos & $A Z$ & 293,541 & 127 & 3 \\
\hline Isleta Pueblo & NM & 263,889 & 115 & 2 \\
\hline Nambe Pueblo & NM & 259,015 & 112 & 2 \\
\hline San Ildefonso Pueblo & NM & 229,473 & 100 & 2 \\
\hline Coeur d'Alene & WA, ID & 188,412 & 98 & 2 \\
\hline White Mountain & $\mathrm{AZ}$ & 154,092 & 67 & 1 \\
\hline Blackfeet & MT & 154,001 & 83 & 2 \\
\hline
\end{tabular}




\section{Solar PV: Rural Utility Scale}

The total technical potential on tribal lands for electricity generation from utility-scale rural solar resource is about 9 billion MWh, or 3.3\% of total U.S. generation potential. The top tribal lands in terms of potential generation are Navajo (2 billion MWh), Tohono O'odham (900 million MWh), and Fort Peck (450 million MWh). Developable potential of utility-scale solar is often limited by transmission availability and access. A full list of technical potential by tribal land is listed in Appendix 2.

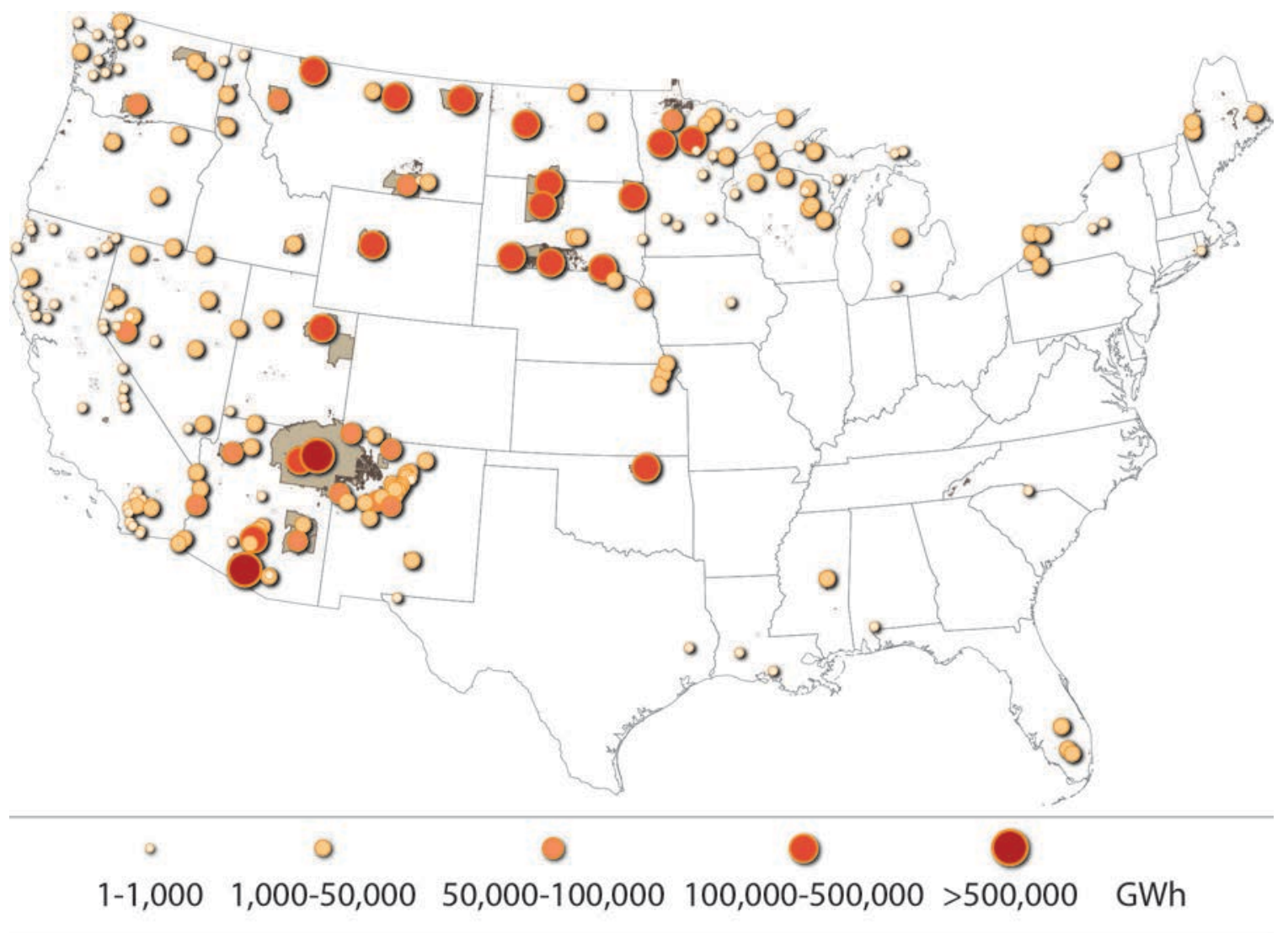

Figure 7. Tribal lands PV utility-scale rural generation potential 
Table 4-8. Top 25 Tribal Lands by Technical Potential for Rural Utility-Scale PV Generation

\begin{tabular}{|c|c|c|c|c|}
\hline Tribal Land & State & $\begin{array}{l}\text { Rural Utility PV } \\
\text { Power Potential } \\
\text { Annual } \\
\text { Generation } \\
\text { (MWh) }\end{array}$ & $\begin{array}{l}\text { Rural Utility } \\
\text { PV Potential } \\
\text { Installed } \\
\text { Capacity } \\
\text { (MW) }\end{array}$ & $\begin{array}{l}\text { Rural Utility PV } \\
\text { Available Land } \\
\left(\mathrm{km}^{2}\right)\end{array}$ \\
\hline Navajo & $\mathrm{NM}, \mathrm{UT}, \mathrm{AZ}, \mathrm{CO}$ & $2,494,474,583$ & $1,087,316$ & 22,652 \\
\hline Hopi & AZ & $2,295,637,379$ & 998,053 & 20,793 \\
\hline Tohono O'odham & $A Z$ & $986,595,977$ & 427,892 & 8,914 \\
\hline Standing Rock & SD, ND & $932,953,632$ & 503,395 & 10,487 \\
\hline Fort Peck & MT & $609,883,158$ & 327,966 & 6,833 \\
\hline Pine Ridge & $\mathrm{NE}, \mathrm{SD}$ & $450,036,180$ & 240,320 & 5,007 \\
\hline Uintah and Ouray & UT & $442,003,250$ & 203,766 & 4,245 \\
\hline Osage & OK & $325,020,763$ & 166,400 & 3,467 \\
\hline Cheyenne River & SD & $323,595,921$ & 172,803 & 3,600 \\
\hline Wind River & WY & $318,333,071$ & 158,647 & 3,305 \\
\hline Blackfeet & MT & $299,959,630$ & 161,304 & 3,361 \\
\hline Rosebud & $\mathrm{NE}, \mathrm{SD}$ & $284,184,572$ & 151,746 & 3,161 \\
\hline Lake Traverse (Sisseton) & SD, MN, ND & $266,608,010$ & 142,810 & 2,975 \\
\hline Zuni Pueblo & $\mathrm{NM}, \mathrm{AZ}$ & $196,586,404$ & 85,349 & 1,778 \\
\hline San Carlos & $A Z$ & $187,916,024$ & 81,500 & 1,698 \\
\hline Crow & WY, MT & $183,354,288$ & 98,599 & 2,054 \\
\hline White Earth & $\mathrm{MN}$ & $180,721,292$ & 109,009 & 2,271 \\
\hline Laguna Pueblo & NM & $172,651,833$ & 74,984 & 1,562 \\
\hline Fort Berthold & ND & $168,674,984$ & 95,006 & 1,979 \\
\hline Fort Belknap & MT & $168,388,007$ & 90,551 & 1,886 \\
\hline Jicarilla Apache & $\mathrm{NM}, \mathrm{CO}$ & $150,130,043$ & 65,203 & 1,358 \\
\hline Hualapai & $\mathrm{AZ}$ & $134,901,150$ & 58,507 & 1,219 \\
\hline Leech Lake & $\mathrm{MN}$ & $129,919,796$ & 78,366 & 1,633 \\
\hline Gila River & $A Z$ & $129,768,914$ & 56,282 & 1,173 \\
\hline Yankton & $\mathrm{NE}, \mathrm{SD}$ & $121,296,780$ & 64,759 & 1,349 \\
\hline
\end{tabular}




\section{Wind}

The total technical potential on tribal lands for electricity generation from wind resources is about 1.1 billion MWh, or about 3.4\% of the total U.S. technical potential. The top four tribal lands in terms of potential generation are Cheyenne River (183 million MWh), Standing Rock (145 million MWh), Fort Peck (122 million MWh), and Pine Ridge (110 million MWh). Developable potential of utility-scale wind, particularly in the Midwest where the resource is strongest but typically far from energy intense population centers, is often limited by transmission availability and access. A full list of technical potential by tribal land is listed in Appendix 2.

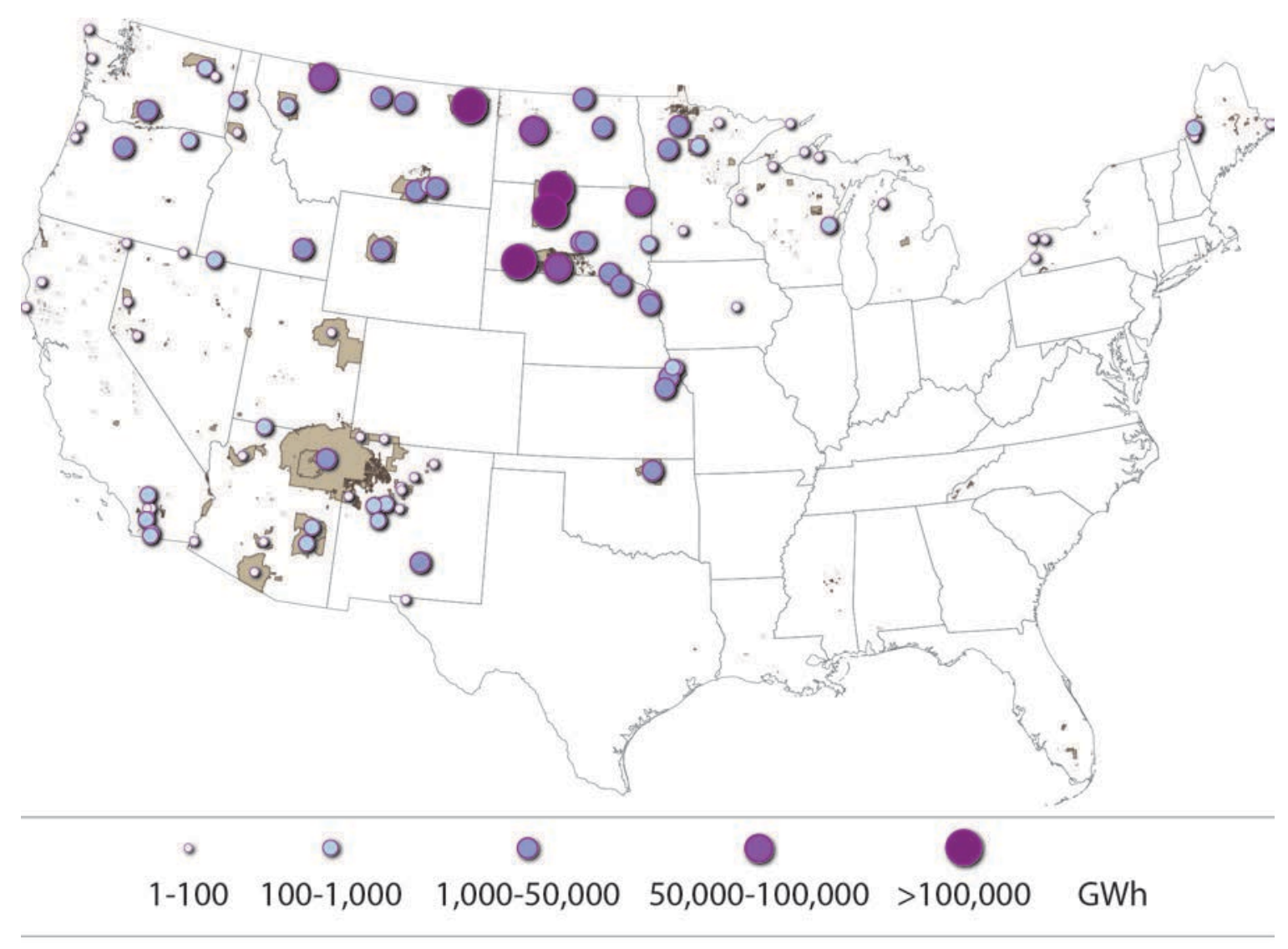

Figure 8. Tribal lands wind generation potential 


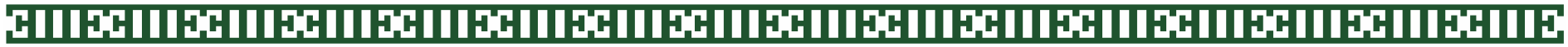

Table 4-9. Top 25 Tribal Lands by Technical Potential for Wind Electricity Generation

\begin{tabular}{|c|c|c|c|c|}
\hline Tribal Land & State & $\begin{array}{l}\text { Wind } \\
\text { Potential } \\
\text { Annual } \\
\text { Generation at } \\
80 \mathrm{~m} \text { and } \\
\text { GCF>=30\% } \\
(\mathrm{MWh})\end{array}$ & $\begin{array}{l}\text { Wind Potential } \\
\text { Installed } \\
\text { Capacity at } 80 \\
\text { m and GCF>= } \\
30 \%(\mathrm{MW})\end{array}$ & $\begin{array}{l}\text { Wind Available } \\
\text { Land at } 80 \mathrm{~m} \\
\text { and GCF>= } \\
30 \%\left(\mathrm{~km}^{2}\right)\end{array}$ \\
\hline Cheyenne River & SD & $188,088,492$ & 57,806 & 11,561 \\
\hline Standing Rock & $\mathrm{SD}, \mathrm{ND}$ & $149,093,091$ & 45,972 & 9,194 \\
\hline Fort Peck & $\mathrm{MT}$ & $126,258,676$ & 41,331 & 8,266 \\
\hline Pine Ridge & NE, SD & $113,398,124$ & 38,028 & 7,606 \\
\hline Rosebud & NE, SD & $87,002,780$ & 25,833 & 5,167 \\
\hline Blackfeet & $\mathrm{MT}$ & $69,911,790$ & 24,476 & 4,895 \\
\hline Lake Traverse (Sisseton) & $\mathrm{SD}, \mathrm{MN}, \mathrm{ND}$ & $60,824,322$ & 17,736 & 3,547 \\
\hline Fort Berthold & ND & $51,781,459$ & 16,409 & 3,282 \\
\hline Osage & $\mathrm{OK}$ & $43,853,495$ & 16,357 & 3,271 \\
\hline Crow & WY, MT & $43,407,456$ & 16,497 & 3,299 \\
\hline Fort Belknap & $\mathrm{MT}$ & $32,739,605$ & 11,725 & 2,345 \\
\hline Yankton & NE, SD & $21,573,834$ & 6,732 & 1,346 \\
\hline White Earth & $\mathrm{MN}$ & $19,367,345$ & 7,400 & 1,480 \\
\hline Crow Creek & SD & $17,699,282$ & 5,722 & 1,144 \\
\hline Lower Brule & SD & $14,521,816$ & 4,509 & 902 \\
\hline Devils Lake Sioux & ND & $14,300,155$ & 4,533 & 907 \\
\hline Omaha & IA, NE & $12,508,456$ & 3,919 & 784 \\
\hline Wind River & WY & $12,306,226$ & 4,345 & 869 \\
\hline Northern Cheyenne & MT & $9,371,963$ & 3,522 & 704 \\
\hline Winnebago & $\mathrm{IA}, \mathrm{NE}$ & $6,601,533$ & 2,094 & 419 \\
\hline Santee & NE & $6,489,284$ & 2,118 & 424 \\
\hline Mescalero Apache & NM & $5,566,143$ & 2,240 & 448 \\
\hline Fort Hall & ID & $5,031,295$ & 2,026 & 405 \\
\hline Potawatomi Prairie Band & KS & $4,562,289$ & 1,548 & 310 \\
\hline Yakama & WA & $3,720,634$ & 1,383 & 277 \\
\hline
\end{tabular}




\section{Conclusion}

This report provides a summary of the technical potential for capacity and generation from a variety of renewable resources on tribal lands. It is intended to provide information to Tribes and researchers as to the opportunity for development on tribal lands. Table A2-1 summarizes the estimated technical generation and capacity potential on tribal lands for each renewable electricity technology examined in this report. As estimates of technical, rather than economic or market potential, these values do not consider:

- Allocation of available land among technologies (available land is generally assumed to be available to support development of more than one technology, and each set of exclusions was applied independently)

- Availability of existing or planned transmission infrastructure that is necessary to tie generation into the electricity grid

- The dependability of consistent electricity generation, at a time coincident to when electricity is used

- The cost associated with developing power at any location

- Presence of local, state, regional, or national policies, either existing or potential, that could encourage renewable development

- The location or magnitude of current and potential areas of electricity need.

Overall, the analysis shows that the technical potential on tribal lands is about $6 \%$ of the total national technical potential. This is disproportionately larger than the $2 \%$ tribal lands in the United States, indicating an increased potential density for renewable energy development on tribal lands. Next steps for understanding the developable potential of renewable energy on tribal lands include assessing tribal interests in development (e.g., scale of project, purpose of project, cultural sensitivity avoidance); understanding the energy environment in which the project would function as a way of assessing potential project viability and economics; and working with the local utility and regulatory authorities to understand renewable energy needs.

Updates to these technical potentials are possible on an ongoing basis as resource, system, exclusions, and domain knowledge change and data sets improve in quality and resolution. 


\section{References}

Doris, E.; Taylor, R. (2009). 2008 Weatherization and Intergovernmental Program Report. TP-6A243614; DOE/GO-102009-2859. Golden, CO: National Renewable Energy Laboratory. Accessed Aug. 15, 2012: http://www.nrel.gov/docs/fy09osti/43614.pdf.

Lopez, A.; Roberts, B.; Heimiller, D.; Blair, N.; Porro, G. (2012). 2012 U.S. Renewable Energy Technical Potentials: A GIS-Based Analysis. NREL TP-6A20-51946. Accessed August 15, 2012:

http://www.nrel.gov/docs/fy12osti/51946.pdf.

Porro, G.; Heimiller, D. (2006). Report to Congress on Renewable Energy Resource Assessment Information for the United States - EPACT 201 Report. NREL TP-6A20-50168; DOE/GO-102010-3206. Golden, CO: National Renewable Energy Laboratory. 


\section{Appendix 1. Exclusions and Constraints, Capacity Factors, and Power Densities}

Table A-1. Exclusions and Constraints for Urban Utility-Scale Photovoltaics

\begin{tabular}{lll}
\hline Slope Exclusion & $>3 \%$ & \\
Contiguous Area Exclusion & $<0.018 \mathrm{~km}^{2}$ & \\
Land Type(s) Exclusion & Within Urban Boundaries & ESRI (2004) \\
& Landmarks & ESRI (2007a) \\
& Parks & ESRI (2007b) \\
& MRLC-Water & MRLC (n.d.) \\
& MRLC-Wetlands & MRLC (n.d.) \\
& MRLC-Forests & MRLC (n.d.) \\
& MRLC-Impervious Surface >= & MRLC (n.d.) \\
& & \\
\hline
\end{tabular}

Table A-2. Capacity Factors for Utility-Scale Photovoltaics ${ }^{a}$

\begin{tabular}{lclclc}
\hline State & Capacity Factor & State & Capacity Factor & State & Capacity Factor \\
\hline Alabama & 0.200 & Maine & 0.191 & Oklahoma & 0.223 \\
Alaska & 0.105 & Maryland & 0.179 & Oregon & 0.227 \\
Arizona & 0.263 & Massachusetts & 0.182 & Pennsylvania & 0.177 \\
Arkansas & 0.207 & Michigan & 0.173 & Rhode Island & 0.176 \\
California & 0.252 & Minnesota & 0.189 & South Carolina & 0.202 \\
Colorado & 0.259 & Mississippi & 0.197 & South Dakota & 0.214 \\
Connecticut & 0.182 & Missouri & 0.193 & Tennessee & 0.201 \\
Delaware & 0.186 & Montana & 0.212 & Texas & 0.218 \\
Florida & 0.209 & Nebraska & 0.217 & Utah & 0.248 \\
Georgia & 0.203 & Nevada & 0.263 & Vermont & 0.176 \\
Hawaii & 0.210 & New Hampshire & 0.184 & Virginia & 0.200 \\
Idaho & 0.220 & New Jersey & 0.200 & Washington & 0.199 \\
Illinois & 0.186 & New Mexico & 0.263 & West Virginia & 0.172 \\
Indiana & 0.184 & New York & 0.184 & Wisconsin & 0.180 \\
lowa & 0.199 & North Carolina & 0.206 & Wyoming & 0.229 \\
Kansas & 0.238 & North Dakota & 0.203 & & \\
Kentucky & 0.186 & Ohio & 0.173 & & \\
Louisiana & 0.196 & & & &
\end{tabular}




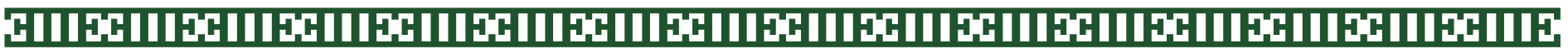

\section{Table A-3. Exclusions and Constraints for Rural Utility-Scale Photovoltaics and Concentrating Solar Power}

\begin{tabular}{|c|c|c|}
\hline $\begin{array}{l}\text { Slope Exclusion } \\
\text { Contiguous Area }\end{array}$ & $\begin{array}{l}>3 \% \\
<1 \mathrm{~km}^{2}\end{array}$ & \\
\hline Exclusion & & \\
\hline Land Type(s) & Urban Areas & ESRI (2004) \\
\hline & MRLC-Water & MRLC (n.d.) \\
\hline & MRLC-Wetlands & MRLC (n.d.) \\
\hline & BLM ACEC Lands (Areas of Critical & BLM (2009) \\
\hline & Environmental Concern) (BLM 2009) & \\
\hline & $\begin{array}{l}\text { Forest Service IRA (Inventoried Roadless Area) } \\
\text { (USFS 2003) }\end{array}$ & USFS (2003) \\
\hline & National Park Service Lands & USGS (2005) \\
\hline & Fish \& Wildlife Lands & USGS (2005) \\
\hline & Federal Parks & USGS (2005) \\
\hline & Federal Wilderness & USGS (2005) \\
\hline & Federal Wilderness Study Area & USGS (2005) \\
\hline & Federal National Monument & USGS (2005) \\
\hline & Federal National Battlefield & USGS (2005) \\
\hline & Federal Recreation Area & USGS (2005) \\
\hline & Federal National Conservation Area & USGS (2005) \\
\hline & Federal Wildlife Refuge & USGS (2005) \\
\hline & Federal Wildlife Area & USGS (2005) \\
\hline & Federal Wild and Scenic Area & USGS (2005) \\
\hline
\end{tabular}

Table A-4. Capacity Factors for Concentrating Solar Power

\begin{tabular}{ccc}
\hline Class & Kwh/m $/$ day & Capacity Factor \\
\cline { 2 - 3 } 1 & $5-6.25$ & 0.315 \\
2 & $6.25-7.25$ & 0.393 \\
3 & $7.25-7.5$ & 0.428 \\
4 & $7.5-7.75$ & 0.434 \\
5 & $>7.75$ & 0.448 \\
\hline${ }^{a}$ System Advisor Model (SAM) &
\end{tabular}




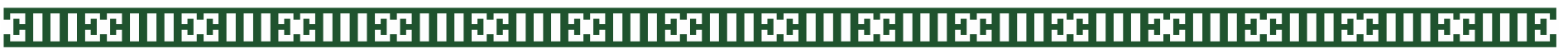

Table A-5. Exclusions and Constraints for Onshore Wind Power

\begin{tabular}{|c|c|c|}
\hline Slope Exclusion & $>20 \%$ & \\
\hline Distance & $<3 \mathrm{~km}$ Distance to Excluded Area (does not apply to & \\
\hline Exclusion & water) & \\
\hline Land Type(s) & $50 \%$ Forest Service Lands (includes National & USGS (2005) \\
\hline Exclusion & Grasslands, excludes ridge crests) & \\
\hline & $\begin{array}{l}50 \% \text { Department of Defense Lands (excludes ridge } \\
\text { crest) }\end{array}$ & USGS (2005) \\
\hline & 50\% GAP Land Stewardship Class 2-Forest & CBI (2004) \\
\hline & $\begin{array}{l}50 \% \text { Exclusion of Non-Ridge Crest Forest (noncumulative } \\
\text { over Forest Service land) }\end{array}$ & USGS (2005) \\
\hline & Airports & ESRI (2003) \\
\hline & Urban Areas & ESRI (2004) \\
\hline & LULC-Wetlands & USGS (1993) \\
\hline & LULC-Water & USGS (1993) \\
\hline & Forest Service IRA (Inventoried Roadless Areas) & USFS (2003) \\
\hline & National Park Service Lands & USGS (2005) \\
\hline & Fish and Wildlife Lands & USGS (2005) \\
\hline & Federal Parks & USGS (2005) \\
\hline & Federal Wilderness & USGS (2005) \\
\hline & Federal Wilderness Study Area & USGS (2005) \\
\hline & Federal National Monument & USGS (2005) \\
\hline & Federal National Battlefield & USGS (2005) \\
\hline & Federal Recreation Area & USGS (2005) \\
\hline & Federal National Conservation Area & USGS (2005) \\
\hline & Federal Wildlife Refuge & USGS (2005) \\
\hline & Federal Wildlife Area & USGS (2005) \\
\hline & Federal Wild and Scenic Area & USGS (2005) \\
\hline & $\begin{array}{l}\text { GAP Land Stewardship Class 2-State and Private Lands } \\
\text { Equivalent to Federal Exclusions }\end{array}$ & CBI (2004) \\
\hline
\end{tabular}




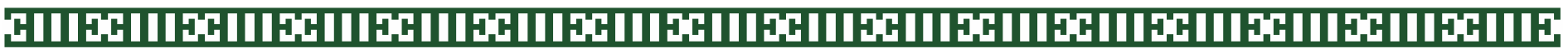

Table A-6. Capacity Factor for Offshore Wind Power ${ }^{a}$

\begin{tabular}{lcll}
\hline Depth & Class & Watts $/ \mathrm{m}^{2}$ & Capacity Factor \\
\cline { 2 - 4 } Shallow & \multicolumn{3}{l}{} \\
0-30 meters & 3 & $300-400$ & 0.36 \\
$0-30$ meters & 4 & $400-500$ & 0.39 \\
0-30 meters & 5 & $500-600$ & 0.45 \\
0-30 meters & 6 & $600-800$ & 0.479 \\
0-30 meters & 7 & $>800$ & 0.5 \\
Deep & & & \\
$>30$ meters & 3 & $300-400$ & 0.367 \\
$>30$ meters & 4 & $400-500$ & 0.394 \\
$>30$ meters & 5 & $500-600$ & 0.45 \\
$>30$ meters & 6 & $600-800$ & 0.479 \\
$>30$ meters & 7 & $>800$ & 0.5 \\
\hline${ }^{2}$ Regional Energy Deployment System (ReEDS)
\end{tabular}

Table A-7. Conversion of Offshore Wind Speeds at 90 Meters to Power Classes ${ }^{a}$

\begin{tabular}{cc}
\hline Wind Speed $(\mathrm{m} / \mathrm{s})$ & Power Class \\
\cline { 2 - 2 } $6.4-7.0$ & 3 \\
$7.0-7.5$ & 4 \\
$7.5-8.0$ & 5 \\
$8.0-8.8$ & 6 \\
$>8.8$ & 7 \\
\hline${ }^{a}$ Marc Schwartz, NREL wind analyst, personal communication
\end{tabular}


Table A-8. Exclusions and Constraints for Offshore Wind Power ${ }^{a}$

\begin{tabular}{|c|c|}
\hline \multicolumn{2}{|l|}{$\begin{array}{l}\text { Distance Exclusion } \\
\text { Land Type(s) Exclusion }\end{array}$} \\
\hline \multirow[t]{10}{*}{ Federal Exclusions } & National Marine Sanctuaries \\
\hline & Marine Protected Areas Inventory-“NAL,” “NIL,” “NTL” \\
\hline & Office of Habitat Conservation Habitat Protection Div. EFH- \\
\hline & $\begin{array}{l}\text { Shipping Routes, Sanctuary Protected Areas } \\
\text { NOAA Jurisdictional Boundaries and Limits-Coastal }\end{array}$ \\
\hline & $\begin{array}{l}\text { NOAA Jurisdictional Boundaries and Limits-Coastal } \\
\text { National Wildlife Refuges-Pacific }\end{array}$ \\
\hline & Navigational \& Marine Infrastructure-Shipping Lanes, \\
\hline & Drilling Platforms (Gulf), Pipelines (Gulf), Fairways (Gulf) \\
\hline & NWIOOS-Towlane Agreement WSG 2007 \\
\hline & World Database on Protected Areas Annual Release 2009 \\
\hline & $\begin{array}{l}\text { Global Dataset-Offshore Oil and Gas Pipelines/Drilling } \\
\text { Platforms }\end{array}$ \\
\hline \multirow[t]{8}{*}{ Texas } & Pipelines and Easements \\
\hline & Audubon Sanctuaries \\
\hline & Gulf Intercoastal Waterway/Ship Channels \\
\hline & National Wildlife Refuges \\
\hline & Shipping Safety Fairways \\
\hline & State Coastal Preserves \\
\hline & Dredged Material Placement Sites \\
\hline & State Tracts with Resource Management Codes \\
\hline \multirow[t]{3}{*}{ North Carolina } & Significant Natural Heritage Areas \\
\hline & Sea Turtle Sanctuary \\
\hline & Crane Spawning Sanctuary \\
\hline \multirow[t]{2}{*}{ Great Lakes } & IM AOC EPA \\
\hline & IM Ship Routes \\
\hline \multirow[t]{6}{*}{ Virginia } & Near-shore Coastal Parks \\
\hline & Threatened and Endangered Species Waters \\
\hline & Crab Sanctuary \\
\hline & Security Areas \\
\hline & Striped Bass Sanctuary \\
\hline & $\begin{array}{l}\text { State Park and State Dedicated Natural Area Preserve } \\
\text { (w/in } 1 \text { mile of shoreline) }\end{array}$ \\
\hline \multirow[t]{3}{*}{ Rhode Island } & Habitat Restoration Area \\
\hline & $\begin{array}{l}\text { Hazardous Material Sites Designated by the U.S. EPA and } \\
\text { RIDEM (w/in } 0.5 \text { miles of shoreline) }\end{array}$ \\
\hline & CRMCWTO8 $($ Type $=1$ or 2$)$ \\
\hline \multirow[t]{2}{*}{ South Carolina } & Refuges \\
\hline & OCRM Critical Area \\
\hline New Hampshire & Conservation Focus Area \\
\hline \multirow[t]{2}{*}{ Florida } & Ocean Dredged Material Disposal Sites \\
\hline & $\begin{array}{l}\text { Aquatic Preserve Boundaries } \\
\text { Cordell Banks closed Areas }\end{array}$ \\
\hline
\end{tabular}




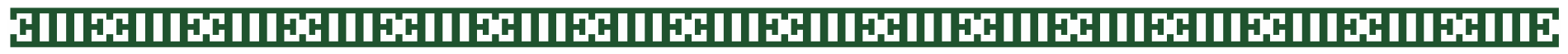

Massachusetts

Oregon

New Jersey
Ferry Routes

Oregon Islands National Wildlife Refuges USFWS 2004

Oregon Marine Managed Areas

Oregon Cables OFCC 2005

Dredged Material Disposal Sites ACOE 2008

New Jersey Coastal Wind Turbine Siting Map-Exclusion

Areas

${ }^{a}$ Exclusions were developed by Black and Veatch (2009).

Table A-9. Exclusions and Constraints for Enhanced Geothermal Systems ${ }^{a}$

\begin{tabular}{ll}
\hline Land Type(s) Exclusion & National Park Service Lands \\
& Fish and Wildlife Service Lands \\
& Federal Parks \\
& Federal Wilderness \\
& Federal National Monuments \\
& Federal National Battlefields \\
& Federal Restoration Areas \\
& Federal National Conservation \\
& Areas \\
& Federal Wildlife Refuge Areas \\
& Federal Wild and Scenic Areas \\
\hline${ }^{a}$ United States Geological Survey (USGS) (2005)
\end{tabular}




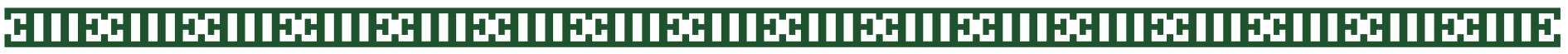

Table A-10. Power Densities for Enhanced Geothermal Systems ${ }^{a}$

\begin{tabular}{cc}
\hline Temperature C & $\mathrm{MW} / \mathrm{km}^{2}$ \\
\cline { 2 - 2 } $150-200$ & 0.59 \\
$200-250$ & 0.76 \\
$250-300$ & 0.86 \\
$300-350$ & 0.97 \\
$>350$ & 1.19 \\
\hline
\end{tabular}

${ }^{a}$ Augustine (2011)

Table A-11. Exclusions and Constraints for Enhanced Geothermal Systems ${ }^{a}$

\begin{tabular}{ll}
\hline Depth Constraints & Depth $>3$ and $<10 \mathrm{~km}$ \\
Land Type(s) Exclusion & National Park Service Lands \\
& Fish and Wildlife Service \\
& Lands \\
& Federal Parks \\
& Federal Wilderness \\
& Federal National \\
& Monuments \\
& Federal National Battlefields \\
& Federal Restoration Areas \\
& Federal Conservation Areas \\
& Federal Wildlife Refuge \\
& Areas \\
& Federal Wild and Scenic \\
& Areas \\
\hline
\end{tabular}

${ }^{\mathrm{a}}$ USGS (2005) 


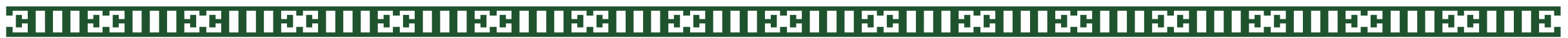

\section{Appendix 2. Technical Potential by Tribal Lands for Renewable Resources}

Table A2-1. Tribal Renewable Energy Potential-Hydrothermal, Hydropower, and Biopower

\begin{tabular}{|c|c|c|c|c|c|c|c|c|c|}
\hline Tribal Land & State & $\begin{array}{l}\text { Unidentified } \\
\text { Hydrothermal } \\
\text { Potential } \\
\text { Annual } \\
\text { Generation } \\
\text { (MWh) }\end{array}$ & $\begin{array}{l}\text { Unidentified } \\
\text { Hydrothermal } \\
\text { Potential } \\
\text { Installed } \\
\text { Capacity } \\
\text { (MW) }\end{array}$ & $\begin{array}{l}\text { Hydropower } \\
\text { Generation } \\
\text { Potential } \\
\text { (MWh) }\end{array}$ & $\begin{array}{l}\text { Hydropower } \\
\text { Capacity } \\
\text { Potential } \\
\text { (MW) }\end{array}$ & $\begin{array}{l}\text { Biopower } \\
\text { from Solid } \\
\text { Residuesa } \\
\text { (MWh) }\end{array}$ & $\begin{array}{l}\text { Biopower } \\
\text { from Solid } \\
\text { Residues } \\
(\mathrm{MW})\end{array}$ & $\begin{array}{l}\text { Biopower } \\
\text { from } \\
\text { Gaseous } \\
\text { Residues }^{b} \\
\text { (MWh) }\end{array}$ & $\begin{array}{l}\text { Biopower } \\
\text { from } \\
\text { Gaseous } \\
\text { Residues } \\
\text { (MW) }\end{array}$ \\
\hline Acoma Pueblo & NM & 20,363 & 3 & 2,523 & 1 & 0 & 0 & 13 & 0 \\
\hline Agua Caliente & $\mathrm{CA}$ & 475 & 0 & 3,783 & 1 & 6,322 & 1 & 268 & 0 \\
\hline Alabama and Coushatta & $\mathrm{TX}$ & - & - & - & - & 3,493 & 0 & 3 & 0 \\
\hline Alamo (Navajo) & NM & 8,452 & 1 & 1,152 & 0 & 2 & 0 & 1 & 0 \\
\hline Alturas Rancheria & $\mathrm{CA}$ & 8 & 0 & - & - & - & - & 0 & 0 \\
\hline Augustine & $\mathrm{CA}$ & 60 & 0 & - & - & 127 & 0 & 0 & 0 \\
\hline Bad River & WI & - & - & 12,290 & 3 & 32,417 & 4 & 45 & 0 \\
\hline Barona Rancheria & $\mathrm{CA}$ & 96 & 0 & - & - & - & - & 36 & 0 \\
\hline Bay Mills & MI, MI & - & - & 168 & 0 & 22 & 0 & 1 & 0 \\
\hline Benton Paiute & $\mathrm{CA}$ & 53 & 0 & - & - & - & - & 0 & 0 \\
\hline Berry Creek Rancheria & $\mathrm{CA}$ & 0 & 0 & - & - & 5 & 0 & 0 & 0 \\
\hline Big Bend Rancheria & $\mathrm{CA}$ & 11 & 0 & - & - & 21 & 0 & 0 & 0 \\
\hline Big Cypress & $\mathrm{FL}$ & - & - & - & - & 15,013 & 2 & 17 & 0 \\
\hline Big Lagoon Rancheria & $\mathrm{CA}$ & - & - & - & - & 5 & 0 & 0 & 0 \\
\hline Big Pine Rancheria & $\mathrm{CA}$ & 83 & 0 & - & - & - & - & 0 & 0 \\
\hline Big Sandy Rancheria & $\mathrm{CA}$ & 1 & 0 & - & - & 5 & 0 & 0 & 0 \\
\hline Big Valley Rancheria & $\mathrm{CA}$ & 258 & 0 & - & - & 64 & 0 & 0 & 0 \\
\hline Bishop Rancheria & $\mathrm{CA}$ & 521 & 0 & - & - & 448 & 0 & 0 & 0 \\
\hline Blackfeet & MT & 60,031 & 8 & 445,893 & 102 & 87,202 & 11 & 98 & 0 \\
\hline Blue Lake Rancheria & $\mathrm{CA}$ & 1 & 0 & - & - & 20 & 0 & 0 & 0 \\
\hline Bois Forte (Nett Lake) & MN & - & - & - & - & 28,872 & 4 & 3 & 0 \\
\hline Bridgeport Colony & $\mathrm{CA}$ & 18 & 0 & - & - & - & - & 0 & 0 \\
\hline Brighton & $\mathrm{FL}$ & - & - & - & - & 18,809 & 2 & 24 & 0 \\
\hline Burns Paiute & OR & 2,436 & 0 & - & - & 21 & 0 & 0 & 0 \\
\hline Cabazon & $\mathrm{CA}$ & 604 & 0 & 112 & 0 & 124 & 0 & 44 & 0 \\
\hline Cahuilla & $\mathrm{CA}$ & 511 & 0 & 241 & 0 & 67 & 0 & 7 & 0 \\
\hline Camp Verde & $\mathrm{AZ}$ & 25 & 0 & - & - & 26 & 0 & 1 & 0 \\
\hline Campo & $\mathrm{CA}$ & 760 & 0 & 307 & 0 & - & - & 3 & 0 \\
\hline
\end{tabular}


Geospatial Analysis of Renewable Energy Technical Potential on Tribal Lands

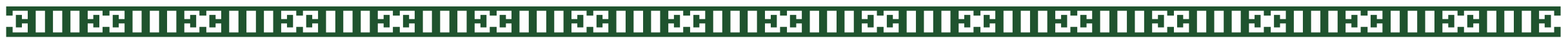

\begin{tabular}{|c|c|c|c|c|c|c|c|c|c|}
\hline Tribal Land & State & $\begin{array}{l}\text { Unidentified } \\
\text { Hydrothermal } \\
\text { Potential } \\
\text { Annual } \\
\text { Generation } \\
\text { (MWh) }\end{array}$ & $\begin{array}{l}\text { Unidentified } \\
\text { Hydrothermal } \\
\text { Potential } \\
\text { Installed } \\
\text { Capacity } \\
\text { (MW) }\end{array}$ & $\begin{array}{l}\text { Hydropower } \\
\text { Generation } \\
\text { Potential } \\
\text { (MWh) }\end{array}$ & $\begin{array}{l}\text { Hydropower } \\
\text { Capacity } \\
\text { Potential } \\
\text { (MW) }\end{array}$ & $\begin{array}{l}\text { Biopower } \\
\text { from Solid } \\
\text { Residuesa } \\
\text { (MWh) }\end{array}$ & $\begin{array}{l}\text { Biopower } \\
\text { from Solid } \\
\text { Residues } \\
\text { (MW) }\end{array}$ & $\begin{array}{l}\text { Biopower } \\
\text { from } \\
\text { Gaseous } \\
\text { Residues }^{b} \\
\text { (MWh) } \\
\end{array}$ & $\begin{array}{l}\text { Biopower } \\
\text { from } \\
\text { Gaseous } \\
\text { Residues } \\
\text { (MW) } \\
\end{array}$ \\
\hline Capitan Grande & $\mathrm{CA}$ & 165 & 0 & 1,624 & 0 & - & - & 16 & 0 \\
\hline Carson Colony & NV & 66 & 0 & - & - & 58 & 0 & 0 & 0 \\
\hline Catawba & SC & - & - & - & - & 645 & 0 & 4 & 0 \\
\hline Cattaraugus (Seneca) & NY & - & - & 9,678 & 2 & 971 & 0 & 26 & 0 \\
\hline Cedarville Rancheria & $\mathrm{CA}$ & 21 & 0 & - & - & 0 & 0 & 0 & 0 \\
\hline Chehalis & WA & 10 & 0 & 1,545 & 0 & 3,205 & 0 & 2 & 0 \\
\hline Chemehuevi & $\mathrm{CA}$ & 4,412 & 1 & - & - & - & - & 2 & 0 \\
\hline Cheyenne River & SD & - & - & 47,065 & 11 & 35,581 & 5 & 68 & 0 \\
\hline Chicken Ranch Rancheria & $\mathrm{CA}$ & 0 & 0 & - & - & 0 & 0 & 0 & 0 \\
\hline Chitimacha & LA & - & - & - & - & 172 & 0 & 2 & 0 \\
\hline Cochiti Pueblo & NM & 17,958 & 2 & 25,682 & 6 & 39 & 0 & 33 & 0 \\
\hline Cocopah & $\mathrm{AZ}, \mathrm{CA}$ & 1,368 & 0 & - & - & 1,161 & 0 & 25,403 & 3 \\
\hline Coeur d'Alene & WA,ID & 24,563 & 3 & 18,416 & 4 & 264,737 & 34 & 84 & 0 \\
\hline Cold Springs Rancheria & $\mathrm{CA}$ & 0 & 0 & - & - & 1 & 0 & 0 & 0 \\
\hline Colorado River & $\mathrm{AZ}, \mathrm{CA}$ & 41,401 & 5 & 106,505 & 24 & 17,814 & 2 & 34 & 0 \\
\hline Colusa (Cachil Dehe) Rancheria & CA & 1 & 0 & - & - & 13 & 0 & 0 & 0 \\
\hline Colville & WA & 70,390 & 9 & 247,936 & 57 & 59,616 & 8 & 89 & 0 \\
\hline Coos, Lower Umpqua, and Siuslaw & OR & 0 & 0 & - & - & 5 & 0 & 0 & 0 \\
\hline Cortina Rancheria & $\mathrm{CA}$ & 40 & 0 & - & - & - & - & 0 & 0 \\
\hline Coushatta & LA & - & - & - & - & 73 & 0 & 0 & 0 \\
\hline Cow Creek & OR & 0 & 0 & - & - & - & - & 0 & 0 \\
\hline Coyote Valley & $\mathrm{CA}$ & 22 & 0 & - & - & 72 & 0 & 0 & 0 \\
\hline Crow & WY, MT & 28,073 & 4 & 89,049 & 20 & 43,001 & 5 & 229 & 0 \\
\hline Crow Creek & SD & - & - & 3,303 & 1 & 23,293 & 3 & 18 & 0 \\
\hline Crow/Northern Cheyenne Area & MT & 417 & 0 & - & - & 17 & 0 & 0 & 0 \\
\hline Cuyapaipe & $\mathrm{CA}$ & 227 & 0 & - & - & - & - & 1 & 0 \\
\hline Deer Creek & MN & - & - & - & - & 1,800 & 0 & 1 & 0 \\
\hline Devils Lake Sioux & ND & - & - & - & - & 46,079 & 6 & 32 & 0 \\
\hline Dresslerville Colony & NV & 15 & 0 & - & - & 14 & 0 & 0 & 0 \\
\hline Dry Creek Rancheria & $\mathrm{CA}$ & 192 & 0 & - & - & 6 & 0 & 0 & 0 \\
\hline Duck Valley & $\mathrm{NV}, \mathrm{ID}$ & 164,004 & 21 & 14,913 & 3 & - & - & 2 & 0 \\
\hline Duckwater & NV & 915 & 0 & - & - & - & - & 0 & 0 \\
\hline Eastern Cherokee & $\mathrm{NC}$ & - & - & 13,299 & 3 & 3,223 & 0 & 25 & 0 \\
\hline Elk Valley Rancheria & $\mathrm{CA}$ & 1 & 0 & - & - & 29 & 0 & 0 & 0 \\
\hline Ely Colony & NV & 57 & 0 & - & - & 60 & 0 & 0 & 0 \\
\hline Enterprise Rancheria & $\mathrm{CA}$ & 0 & 0 & - & - & 6 & 0 & 0 & 0 \\
\hline
\end{tabular}


Geospatial Analysis of Renewable Energy Technical Potential on Tribal Lands

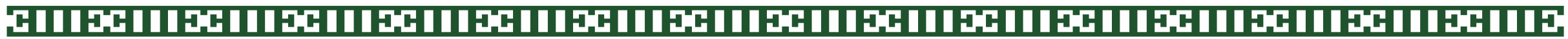

\begin{tabular}{|c|c|c|c|c|c|c|c|c|c|}
\hline Tribal Land & State & $\begin{array}{l}\text { Unidentified } \\
\text { Hydrothermal } \\
\text { Potential } \\
\text { Annual } \\
\text { Generation } \\
\text { (MWh) }\end{array}$ & $\begin{array}{l}\text { Unidentified } \\
\text { Hydrothermal } \\
\text { Potential } \\
\text { Installed } \\
\text { Capacity } \\
\text { (MW) }\end{array}$ & $\begin{array}{l}\text { Hydropower } \\
\text { Generation } \\
\text { Potential } \\
\text { (MWh) }\end{array}$ & $\begin{array}{l}\text { Hydropower } \\
\text { Capacity } \\
\text { Potential } \\
\text { (MW) }\end{array}$ & $\begin{array}{l}\text { Biopower } \\
\text { from Solid } \\
\text { Residues } \\
\text { (MWh) }\end{array}$ & $\begin{array}{l}\text { Biopower } \\
\text { from Solid } \\
\text { Residues } \\
(\mathrm{MW})\end{array}$ & $\begin{array}{l}\text { Biopower } \\
\text { from } \\
\text { Gaseous } \\
\text { Residues }^{b} \\
\text { (MWh) }\end{array}$ & $\begin{array}{l}\text { Biopower } \\
\text { from } \\
\text { Gaseous } \\
\text { Residues } \\
\text { (MW) }\end{array}$ \\
\hline Fallon & NV & 6,611 & 1 & - & - & - & - & 1 & 0 \\
\hline Fallon Colony & NV & 75 & 0 & - & - & 19 & 0 & 0 & 0 \\
\hline Flandreau & SD & - & - & 621 & 0 & 1,565 & 0 & 0 & 0 \\
\hline Flathead & MT & 151,999 & 19 & 816,341 & 186 & $\begin{array}{r}123,57 \\
2\end{array}$ & 16 & 262 & 0 \\
\hline Fond du Lac & $\mathrm{MN}$ & - & - & 8,042 & 2 & 41,847 & 5 & 86 & 0 \\
\hline Fort Belknap & MT & 7,786 & 1 & 5,108 & 1 & 16,216 & 2 & 14 & 0 \\
\hline Fort Berthold & ND & - & - & 3,819 & 1 & 109,151 & 14 & 43 & 0 \\
\hline Fort Bidwell & $\mathrm{CA}$ & 3,080 & 0 & 1,265 & 0 & 47 & 0 & 0 & 0 \\
\hline Fort Hall & ID & 179,275 & 23 & 70,593 & 16 & 101,896 & 13 & 210 & 0 \\
\hline Fort Independence & $\mathrm{CA}$ & 50 & 0 & - & - & - & - & 0 & 0 \\
\hline Fort McDermitt & $\mathrm{NV}, \mathrm{OR}$ & 18,956 & 2 & 2,347 & 1 & 3 & 0 & 0 & 0 \\
\hline Fort Mojave & $\mathrm{NV}, \mathrm{AZ}, \mathrm{CA}$ & 4,992 & 1 & 3,050 & 1 & 565 & 0 & 50 & 0 \\
\hline Fort Peck & MT & 120,159 & 15 & 57,645 & 13 & 159,234 & 20 & 71 & 0 \\
\hline Fort Yuma (Quechan) & $\mathrm{AZ}, \mathrm{CA}$ & 9,903 & 1 & 12,331 & 3 & 2,518 & 0 & 7 & 0 \\
\hline Gila Bend (TON) & $\mathrm{AZ}$ & 112 & 0 & - & - & 1 & 0 & 0 & 0 \\
\hline Gila River & $\mathrm{AZ}$ & 27,789 & 4 & 47,987 & 11 & 26,922 & 3 & 459 & 0 \\
\hline Goshute & NV, UT & 44,152 & 6 & 5,833 & 1 & 75 & 0 & 1 & 0 \\
\hline Grand Portage & $\mathrm{MN}$ & - & - & 10,877 & 2 & 3,174 & 0 & 3 & 0 \\
\hline Grand Ronde & OR & 23 & 0 & 6,123 & 1 & 20,641 & 3 & 3 & 0 \\
\hline Grand Traverse & $\mathrm{Ml}$ & - & - & - & - & 2 & 0 & 0 & 0 \\
\hline Greenville Rancheria & $\mathrm{CA}$ & 13 & 0 & - & - & 29 & 0 & 0 & 0 \\
\hline Grindstone Creek Rancheria & $\mathrm{CA}$ & 1 & 0 & - & - & - & - & 0 & 0 \\
\hline Hannahville Community & $\mathrm{Ml}$ & - & - & - & - & 763 & 0 & 1 & 0 \\
\hline Havasupai & $\mathrm{AZ}$ & 9,880 & 1 & 5,692 & 1 & 153 & 0 & 4 & 0 \\
\hline Ho-Chunk & $\mathrm{WI}$ & - & - & 1,364 & 0 & 68,939 & 9 & 7 & 0 \\
\hline Hoh & WA & - & - & - & - & 34 & 0 & 0 & 0 \\
\hline Hollywood (Seminole) & $\mathrm{FL}$ & - & - & - & - & 406 & 0 & 29 & 0 \\
\hline Hoopa Valley & $\mathrm{CA}$ & 623 & 0 & 38,550 & 9 & 55,748 & 7 & 10 & 0 \\
\hline Hopi & $\mathrm{AZ}$ & 42,330 & 5 & 1,860 & 0 & 745 & 0 & 62 & 0 \\
\hline Hopland Rancheria & $\mathrm{CA}$ & 31 & 0 & - & - & 10 & 0 & 0 & 0 \\
\hline Hualapai & $\mathrm{AZ}$ & 210,076 & 27 & 897 & 0 & 580 & 0 & 16 & 0 \\
\hline Huron Potawatomi & $\mathrm{MI}$ & - & - & - & - & 51 & 0 & 0 & 0 \\
\hline Inaja-Cosmit & $\mathrm{CA}$ & 48 & 0 & 895 & 0 & - & - & 0 & 0 \\
\hline Indian Township (Passamaquoddy) & $\mathrm{ME}$ & - & - & 157 & 0 & 3,797 & 0 & 4 & 0 \\
\hline lowa & $\mathrm{KS}, \mathrm{NE}, \mathrm{MO}$ & - & - & 237 & 0 & 7,368 & 1 & 2 & 0 \\
\hline
\end{tabular}


Geospatial Analysis of Renewable Energy Technical Potential on Tribal Lands

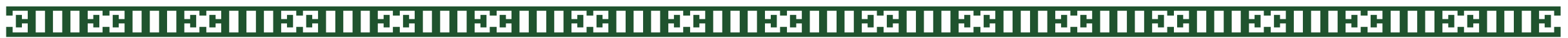

\begin{tabular}{|c|c|c|c|c|c|c|c|c|c|}
\hline Tribal Land & State & $\begin{array}{l}\text { Unidentified } \\
\text { Hydrothermal } \\
\text { Potential } \\
\text { Annual } \\
\text { Generation } \\
\text { (MWh) }\end{array}$ & $\begin{array}{l}\text { Unidentified } \\
\text { Hydrothermal } \\
\text { Potential } \\
\text { Installed } \\
\text { Capacity } \\
\text { (MW) }\end{array}$ & $\begin{array}{l}\text { Hydropower } \\
\text { Generation } \\
\text { Potential } \\
\text { (MWh) }\end{array}$ & $\begin{array}{l}\text { Hydropower } \\
\text { Capacity } \\
\text { Potential } \\
\text { (MW) }\end{array}$ & $\begin{array}{l}\text { Biopower } \\
\text { from Solid } \\
\text { Residuesa } \\
\text { (MWh) }\end{array}$ & $\begin{array}{l}\text { Biopower } \\
\text { from Solid } \\
\text { Residues } \\
\text { (MW) }\end{array}$ & $\begin{array}{l}\text { Biopower } \\
\text { from } \\
\text { Gaseous } \\
\text { Residues }^{b} \\
\text { (MWh) }\end{array}$ & $\begin{array}{l}\text { Biopower } \\
\text { from } \\
\text { Gaseous } \\
\text { Residues } \\
\text { (MW) }\end{array}$ \\
\hline Isabella (Sag Chip) & $\mathrm{MI}$ & - & - & 5,177 & 1 & 41,506 & 5 & 320 & 0 \\
\hline Isleta Pueblo & NM & 44,203 & 6 & 8,483 & 2 & 561 & 0 & 169 & 0 \\
\hline Jackson Rancheria & $\mathrm{CA}$ & 1 & 0 & 418 & 0 & 29 & 0 & 0 & 0 \\
\hline Jamestown S'Klallam & WA & 0 & 0 & - & - & 2 & 0 & 0 & 0 \\
\hline Jamul Village & $\mathrm{CA}$ & 0 & 0 & - & - & - & - & 0 & 0 \\
\hline Jemez Pueblo & NM & 32,709 & 4 & 3,944 & 1 & 25 & 0 & 14 & 0 \\
\hline Jicarilla Apache & $\mathrm{NM}, \mathrm{CO}$ & 143,397 & 18 & 15,647 & 4 & 10,155 & 1 & 16 & 0 \\
\hline Kaibab & $\mathrm{AZ}$ & 17,715 & 2 & 452 & 0 & 14 & 0 & 4 & 0 \\
\hline Kalispel & WA & 177 & 0 & - & - & 923 & 0 & 1 & 0 \\
\hline Karuk & $\mathrm{CA}$ & 1 & 0 & - & - & 88 & 0 & 0 & 0 \\
\hline Kickapoo & KS & - & - & 1,109 & 0 & 10,874 & 1 & 5 & 0 \\
\hline Kootenai & ID & 1 & 0 & - & - & 0 & 0 & 0 & 0 \\
\hline La Jolla & $\mathrm{CA}$ & - & - & 30,993 & 7 & - & - & 9 & 0 \\
\hline La Posta & $\mathrm{CA}$ & 376 & 0 & 516 & 0 & - & - & 1 & 0 \\
\hline Lac Courte Oreilles & $\mathrm{WI}$ & 205 & 0 & 616 & 0 & 27,629 & 4 & 16 & 0 \\
\hline Lac du Flambeau & $\mathrm{WI}$ & - & - & - & - & 12,766 & 2 & 27 & 0 \\
\hline Lac Vieux Desert & $\mathrm{Ml}$ & - & - & - & - & - & - & 0 & 0 \\
\hline Laguna Pueblo & NM & - & - & 8,823 & 2 & 43 & 0 & 38 & 0 \\
\hline Lake Traverse (Sisseton) & SD, MN, ND & 88,772 & 11 & 229 & 0 & 300,466 & 38 & 97 & 0 \\
\hline L'Anse & $\mathrm{MI}$ & - & - & 6,201 & 1 & 7,898 & 1 & 22 & 0 \\
\hline Las Vegas Colony & NV & 509 & 0 & - & - & 10 & 0 & 2 & 0 \\
\hline Laytonville Rancheria & $\mathrm{CA}$ & 15 & 0 & - & - & 54 & 0 & 0 & 0 \\
\hline Leech Lake & $\mathrm{MN}$ & - & - & 1,792 & 0 & 158,657 & 20 & 126 & 0 \\
\hline Likely Rancheria & $\mathrm{CA}$ & 2 & 0 & - & - & 0 & 0 & 0 & 0 \\
\hline Lone Pine Rancheria & $\mathrm{CA}$ & 84 & 0 & - & - & - & - & 888 & 0 \\
\hline Lookout Rancheria & $\mathrm{CA}$ & 29 & 0 & - & - & - & - & 0 & 0 \\
\hline Los Coyotes & $\mathrm{CA}$ & 1,111 & 0 & 362 & 0 & - & - & 2 & 0 \\
\hline Lower Brule & SD & - & - & 225 & 0 & 12,104 & 2 & 11 & 0 \\
\hline Lower Elwha & WA & - & - & - & - & 94 & 0 & 0 & 0 \\
\hline Lower Sioux Community & $\mathrm{MN}$ & - & - & - & - & 874 & 0 & 1 & 0 \\
\hline Lummi & WA & 12 & 0 & 1,263 & 0 & 1,210 & 0 & 50 & 0 \\
\hline Makah & WA & 45 & 0 & 5,908 & 1 & 11,043 & 1 & 3 & 0 \\
\hline Manchester (Point Arena) Rancheria & $\mathrm{CA}$ & 12 & 0 & - & - & 104 & 0 & 0 & 0 \\
\hline Manzanita & $\mathrm{CA}$ & 204 & 0 & 164 & 0 & - & - & 1 & 0 \\
\hline Maricopa (Ak-Chin) & $\mathrm{AZ}$ & 2,313 & 0 & 313 & 0 & 11,100 & 1 & 9 & 0 \\
\hline Mashantucket Pequot & CT & - & - & - & - & 5 & 0 & 5 & 0 \\
\hline
\end{tabular}


Geospatial Analysis of Renewable Energy Technical Potential on Tribal Lands

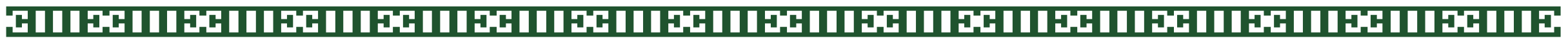

\begin{tabular}{|c|c|c|c|c|c|c|c|c|c|}
\hline Tribal Land & State & $\begin{array}{l}\text { Unidentified } \\
\text { Hydrothermal } \\
\text { Potential } \\
\text { Annual } \\
\text { Generation } \\
\text { (MWh) }\end{array}$ & $\begin{array}{l}\text { Unidentified } \\
\text { Hydrothermal } \\
\text { Potential } \\
\text { Installed } \\
\text { Capacity } \\
\text { (MW) }\end{array}$ & $\begin{array}{l}\text { Hydropower } \\
\text { Generation } \\
\text { Potential } \\
\text { (MWh) }\end{array}$ & $\begin{array}{l}\text { Hydropower } \\
\text { Capacity } \\
\text { Potential } \\
\text { (MW) }\end{array}$ & $\begin{array}{l}\text { Biopower } \\
\text { from Solid } \\
\text { Residuesa } \\
\text { (MWh) }\end{array}$ & $\begin{array}{l}\text { Biopower } \\
\text { from Solid } \\
\text { Residues } \\
(\mathrm{MW})\end{array}$ & $\begin{array}{l}\text { Biopower } \\
\text { from } \\
\text { Gaseous } \\
\text { Residues }^{b} \\
\text { (MWh) }\end{array}$ & $\begin{array}{l}\text { Biopower } \\
\text { from } \\
\text { Gaseous } \\
\text { Residues } \\
\text { (MW) }\end{array}$ \\
\hline Menominee & WI & - & - & 11,198 & 3 & 246,145 & 31 & 42 & 0 \\
\hline Mesa Grande & $\mathrm{CA}$ & 587 & 0 & 593 & 0 & - & - & 1 & 0 \\
\hline Mescalero Apache & NM & 41,007 & 5 & 7,696 & 2 & 10,073 & 1 & 27 & 0 \\
\hline Miccosukee & $\mathrm{FL}$ & - & - & - & - & 17 & 0 & 0 & 0 \\
\hline Middletown Rancheria & $\mathrm{CA}$ & 523 & 0 & - & - & - & - & 0 & 0 \\
\hline Mille Lacs & $\mathrm{MN}$ & - & - & - & - & 117 & 0 & 1 & 0 \\
\hline $\begin{array}{l}\text { Minnesota (Chippewa) Homestead Trust } \\
\text { Lands }\end{array}$ & $\mathrm{MN}$ & - & - & - & - & 88 & 0 & 0 & 0 \\
\hline Mississippi Choctaw & MS & - & - & - & - & 23,696 & 3 & 12 & 0 \\
\hline Moapa Band River & NV & 15,138 & 2 & 784 & 0 & - & - & 4 & 0 \\
\hline Montgomery Creek Rancheria & $\mathrm{CA}$ & 14 & 0 & - & - & 45 & 0 & 0 & 0 \\
\hline Morongo & $\mathrm{CA}$ & 1,515 & 0 & 4,523 & 1 & 183 & 0 & 77 & 0 \\
\hline Muckleshoot & WA & 9 & 0 & 46,137 & 11 & 1,911 & 0 & 56 & 0 \\
\hline Nambe Pueblo & NM & 7,461 & 1 & 2,720 & 1 & 327 & 0 & 13 & 0 \\
\hline Narragansett & $\mathrm{RI}$ & - & - & - & - & 12 & 0 & 6 & 0 \\
\hline Navajo & $\begin{array}{r}\mathrm{NM}, \mathrm{UT}, \mathrm{AZ}, \\
\mathrm{CO}\end{array}$ & 597,545 & 76 & 369,000 & 84 & 103,018 & 13 & 1,755 & 0 \\
\hline Nez Perce & ID & 51,827 & 7 & $1,445,260$ & 330 & 336,781 & 43 & 104 & 0 \\
\hline Nisqually & WA & 12 & 0 & 57,594 & 13 & 3,049 & 0 & 23 & 0 \\
\hline Nooksack & WA & 68 & 0 & 2,473 & 1 & 342 & 0 & 4 & 0 \\
\hline North Fork Rancheria & $\mathrm{CA}$ & 0 & 0 & - & - & - & - & 0 & 0 \\
\hline Northern Cheyenne & MT & 17,254 & 2 & 10,969 & 3 & 16,660 & 2 & 35 & 0 \\
\hline Northwestern Shoshoni & UT & 69 & 0 & 358 & 0 & - & - & 0 & 0 \\
\hline Oil Springs & NY & - & - & - & - & 31 & 0 & 0 & 0 \\
\hline Omaha & $\mathrm{IA}, \mathrm{NE}$ & - & - & 61,961 & 14 & 143,838 & 18 & 44 & 0 \\
\hline Oneida (East) & NY & - & - & - & - & 2 & 0 & 0 & 0 \\
\hline Oneida (West) & $\mathrm{WI}$ & - & - & 723 & 0 & 33,087 & 4 & 232 & 0 \\
\hline Onondaga & NY & - & - & 2,880 & 1 & 727 & 0 & 17 & 0 \\
\hline Ontonagon & $\mathrm{MI}$ & - & - & - & - & 200 & 0 & 0 & 0 \\
\hline Osage & $\mathrm{OK}$ & - & - & 33,957 & 8 & 13,679 & 2 & 659 & 0 \\
\hline Ozette & WA & - & - & - & - & 121 & 0 & 0 & 0 \\
\hline Paiute of Utah & UT & 14,736 & 2 & 2,268 & 1 & 6 & 0 & 24 & 0 \\
\hline Pala & $\mathrm{CA}$ & 789 & 0 & 2,933 & 1 & - & - & 12 & 0 \\
\hline Pascua Yaqui & $\mathrm{AZ}$ & 135 & 0 & - & - & 415 & 0 & 10 & 0 \\
\hline $\begin{array}{l}\text { Passamaquoddy Homestead Trust } \\
\text { Lands }\end{array}$ & ME & - & - & 5,322 & 1 & 12,789 & 2 & 0 & 0 \\
\hline
\end{tabular}


Geospatial Analysis of Renewable Energy Technical Potential on Tribal Lands

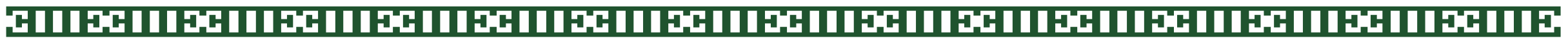

\begin{tabular}{|c|c|c|c|c|c|c|c|c|c|}
\hline Tribal Land & State & $\begin{array}{l}\text { Unidentified } \\
\text { Hydrothermal } \\
\text { Potential } \\
\text { Annual } \\
\text { Generation } \\
\text { (MWh) }\end{array}$ & $\begin{array}{l}\text { Unidentified } \\
\text { Hydrothermal } \\
\text { Potential } \\
\text { Installed } \\
\text { Capacity } \\
\text { (MW) }\end{array}$ & $\begin{array}{l}\text { Hydropower } \\
\text { Generation } \\
\text { Potential } \\
\text { (MWh) }\end{array}$ & $\begin{array}{l}\text { Hydropower } \\
\text { Capacity } \\
\text { Potential } \\
\text { (MW) }\end{array}$ & $\begin{array}{l}\text { Biopower } \\
\text { from Solid } \\
\text { Residuesa } \\
\text { (MWh) }\end{array}$ & $\begin{array}{l}\text { Biopower } \\
\text { from Solid } \\
\text { Residues } \\
\text { (MW) }\end{array}$ & $\begin{array}{l}\text { Biopower } \\
\text { from } \\
\text { Gaseous } \\
\text { Residues }^{b} \\
\text { (MWh) }\end{array}$ & $\begin{array}{l}\text { Biopower } \\
\text { from } \\
\text { Gaseous } \\
\text { Residues } \\
\text { (MW) }\end{array}$ \\
\hline Pauma & $\mathrm{CA}$ & 220 & 0 & - & - & - & - & 2 & 0 \\
\hline Payson (Yavapai-Apache) Community & $\mathrm{AZ}$ & 5 & 0 & - & - & - & - & 0 & 0 \\
\hline Pechanga & $\mathrm{CA}$ & 357 & 0 & - & - & 219 & 0 & 32 & 0 \\
\hline Penobscot & $\mathrm{ME}$ & - & - & 189,260 & 43 & 12,513 & 2 & 13 & 0 \\
\hline Picayune Rancheria & $\mathrm{CA}$ & 0 & 0 & - & - & - & - & 0 & 0 \\
\hline Picuris Pueblo & NM & 11,905 & 2 & 8,657 & 2 & 27 & 0 & 3 & 0 \\
\hline Pine Ridge & $\mathrm{NE}, \mathrm{SD}$ & - & - & 29,895 & 7 & 13,596 & 2 & 124 & 0 \\
\hline Pinoleville Rancheria & $\mathrm{CA}$ & 36 & 0 & - & - & 71 & 0 & 0 & 0 \\
\hline Pit River Tribe of California & $\mathrm{CA}$ & 312 & 0 & 2,098 & 0 & 168 & 0 & 0 & 0 \\
\hline Pleasant Point (Passamaquoddy) & $\mathrm{ME}$ & - & - & - & - & 28 & 0 & 1 & 0 \\
\hline Poarch Creek & $\mathrm{AL}$ & - & - & - & - & 27 & 0 & 0 & 0 \\
\hline Pojoaque Pueblo & NM & 5,128 & 1 & 567 & 0 & 571 & 0 & 7 & 0 \\
\hline Poospatuck & NY & - & - & - & - & 27 & 0 & 2 & 0 \\
\hline Port Gamble & WA & 5 & 0 & - & - & 111 & 0 & 4 & 0 \\
\hline Port Madison & WA & 20 & 0 & - & - & 2,192 & 0 & 61,835 & 8 \\
\hline Potawatomi Forest County & WI & - & - & - & - & 2,377 & 0 & 2 & 0 \\
\hline Potawatomi Prairie Band & KS & - & - & 772 & 0 & 11,095 & 1 & 19 & 0 \\
\hline Prairie Island Community & $\mathrm{MN}$ & - & - & - & - & 65 & 0 & 0 & 0 \\
\hline Puyallup & WA & 46 & 0 & 9,170 & 2 & 15,640 & 2 & 427 & 0 \\
\hline Pyramid Lake & NV & 324,409 & 41 & 31,167 & 7 & 222 & 0 & 8 & 0 \\
\hline Quartz Valley Rancheria & $\mathrm{CA}$ & 1 & 0 & - & - & 76 & 0 & 0 & 0 \\
\hline Quileute & WA & - & - & - & - & 408 & 0 & 0 & 0 \\
\hline Quinault & WA & 406 & 0 & 339,978 & 78 & 161,549 & 20 & 12 & 0 \\
\hline Ramah Navajo Community & NM & 1,875 & 0 & - & - & 0 & 0 & 1 & 0 \\
\hline Ramona & $\mathrm{CA}$ & 26 & 0 & - & - & - & - & 0 & 0 \\
\hline Red Cliff & WI & - & - & - & - & 2,145 & 0 & 3 & 0 \\
\hline Red Lake & $\mathrm{MN}$ & - & - & 117 & 0 & 124,764 & 16 & 54 & 0 \\
\hline Redding Rancheria & $\mathrm{CA}$ & 0 & 0 & - & - & 18 & 0 & 0 & 0 \\
\hline Redwood Valley Rancheria & CA & 29 & 0 & - & - & 69 & 0 & 0 & 0 \\
\hline Reno-Sparks Colony & NV & 1,991 & 0 & - & - & 18 & 0 & 8 & 0 \\
\hline Resighini Rancheria & $\mathrm{CA}$ & 3 & 0 & - & - & 14 & 0 & 0 & 0 \\
\hline Rincon & $\mathrm{CA}$ & 101 & 0 & 968 & 0 & - & - & 7 & 0 \\
\hline Roaring Creek Rancheria & $\mathrm{CA}$ & 22 & 0 & - & - & 39 & 0 & 0 & 0 \\
\hline Robinson Rancheria & $\mathrm{CA}$ & 54 & 0 & - & - & - & - & 0 & 0 \\
\hline Rocky Boy's & MT & 3,044 & 0 & 2,858 & 1 & 18,430 & 2 & 9 & 0 \\
\hline Rohnerville Rancheria & $\mathrm{CA}$ & 1 & 0 & - & - & 27 & 0 & 0 & 0 \\
\hline
\end{tabular}


Geospatial Analysis of Renewable Energy Technical Potential on Tribal Lands

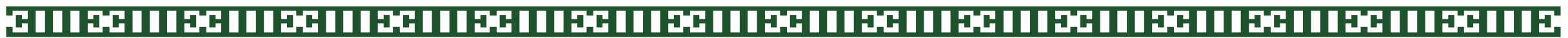

\begin{tabular}{|c|c|c|c|c|c|c|c|c|c|}
\hline Tribal Land & State & $\begin{array}{l}\text { Unidentified } \\
\text { Hydrothermal } \\
\text { Potential } \\
\text { Annual } \\
\text { Generation } \\
\text { (MWh) }\end{array}$ & $\begin{array}{l}\text { Unidentified } \\
\text { Hydrothermal } \\
\text { Potential } \\
\text { Installed } \\
\text { Capacity } \\
\text { (MW) }\end{array}$ & $\begin{array}{l}\text { Hydropower } \\
\text { Generation } \\
\text { Potential } \\
\text { (MWh) }\end{array}$ & $\begin{array}{l}\text { Hydropower } \\
\text { Capacity } \\
\text { Potential } \\
\text { (MW) }\end{array}$ & $\begin{array}{l}\text { Biopower } \\
\text { from Solid } \\
\text { Residuesa } \\
\text { (MWh) }\end{array}$ & $\begin{array}{l}\text { Biopower } \\
\text { from Solid } \\
\text { Residues } \\
(\mathrm{MW})\end{array}$ & $\begin{array}{l}\text { Biopower } \\
\text { from } \\
\text { Gaseous } \\
\text { Residues }^{b} \\
\text { (MWh) } \\
\end{array}$ & $\begin{array}{l}\text { Biopower } \\
\text { from } \\
\text { Gaseous } \\
\text { Residues } \\
\text { (MW) }\end{array}$ \\
\hline Rosebud & $\mathrm{NE}, \mathrm{SD}$ & - & - & 31,800 & 7 & 20,291 & 3 & 85 & 0 \\
\hline Round Valley & $\mathrm{CA}$ & 1,672 & 0 & 20,205 & 5 & 15,239 & 2 & 2 & 0 \\
\hline Rumsey Rancheria & $\mathrm{CA}$ & 2 & 0 & - & - & - & - & 0 & 0 \\
\hline Sac and Fox (lowa) & IA & - & - & 3,564 & 1 & 2,952 & 0 & 2 & 0 \\
\hline Sac and Fox (KS-NE) & $\mathrm{KS}, \mathrm{NE}$ & - & - & 4,678 & 1 & 8,689 & 1 & 5 & 0 \\
\hline Salt River & $\mathrm{AZ}$ & 3,589 & 0 & 17,910 & 4 & 3,495 & 0 & 59,395 & 8 \\
\hline San Carlos & $A Z$ & 179,374 & 23 & 49,442 & 11 & 12,211 & 2 & 76 & 0 \\
\hline San Felipe Pueblo & NM & 13,693 & 2 & 9,678 & 2 & 17 & 0 & 19 & 0 \\
\hline San Felipe/Santa Ana joint area & NM & 191 & 0 & - & - & 0 & 0 & 0 & 0 \\
\hline San Felipe/Santo Domingo joint area & NM & 216 & 0 & - & - & 0 & 0 & 0 & 0 \\
\hline San Ildefonso Pueblo & NM & 11,631 & 1 & 13,036 & 3 & 349 & 0 & 15 & 0 \\
\hline San Juan Pueblo & NM & 10,803 & 1 & 12,465 & 3 & 1,859 & 0 & 48 & 0 \\
\hline San Manuel & $\mathrm{CA}$ & 41 & 0 & - & - & 5 & 0 & 3 & 0 \\
\hline San Pasqual & $\mathrm{CA}$ & 34 & 0 & - & - & - & - & 2 & 0 \\
\hline San Xavier (TON) & $\mathrm{AZ}$ & 13,619 & 2 & 2,638 & 1 & 575 & 0 & 293 & 0 \\
\hline Sandia Pueblo & NM & 4,499 & 1 & 1,770 & 0 & 596 & 0 & 53 & 0 \\
\hline Sandy Lake & $\mathrm{MN}$ & - & - & - & - & 0 & 0 & 0 & 0 \\
\hline Santa Ana Pueblo & NM & 17,965 & 2 & 7,128 & 2 & 133 & 0 & 37 & 0 \\
\hline Santa Clara Pueblo & NM & 34,534 & 4 & 11,984 & 3 & 2,109 & 0 & 104 & 0 \\
\hline Santa Rosa & $\mathrm{CA}$ & 1,390 & 0 & 108 & 0 & - & - & 1 & 0 \\
\hline Santa Rosa Rancheria & $\mathrm{CA}$ & 1 & 0 & - & - & 18 & 0 & 0 & 0 \\
\hline Santa Ynez & $\mathrm{CA}$ & 43 & 0 & - & - & 31 & 0 & 0 & 0 \\
\hline Santa Ysabel & $\mathrm{CA}$ & 1,249 & 0 & 599 & 0 & - & - & 1 & 0 \\
\hline Santee & $\mathrm{NE}$ & - & - & 4,184 & 1 & 27,871 & 4 & 10 & 0 \\
\hline Santo Domingo Pueblo & NM & 20,388 & 3 & 10,871 & 2 & 718 & 0 & 40 & 0 \\
\hline Sauk-Suiattle & WA & 2 & 0 & - & - & 11 & 0 & 0 & 0 \\
\hline Sault Ste. Marie & $\mathrm{MI}, \mathrm{MI}$ & - & - & - & - & 104 & 0 & 1 & 0 \\
\hline Seminole Homestead Trust Lands & $\mathrm{FL}$ & - & - & - & - & 10 & 0 & 0 & 0 \\
\hline Seneca (Allegany) & PA, NY & - & - & - & - & 4,979 & 1 & 17 & 0 \\
\hline Shakopee Community & $\mathrm{MN}$ & - & - & - & - & 126 & 0 & 2 & 0 \\
\hline Sheep Ranch Rancheria & $\mathrm{CA}$ & 0 & 0 & - & - & 0 & 0 & 0 & 0 \\
\hline Sherwood Valley Rancheria & $\mathrm{CA}$ & 37 & 0 & - & - & 81 & 0 & 0 & 0 \\
\hline Shingle Springs Rancheria & $\mathrm{CA}$ & 1 & 0 & - & - & - & - & 0 & 0 \\
\hline Shoalwater & WA & - & - & - & - & 390 & 0 & 0 & 0 \\
\hline Siletz & $\mathrm{OR}$ & 9 & 0 & - & - & 1,072 & 0 & 1 & 0 \\
\hline Skokomish & WA & 12 & 0 & 15,169 & 3 & 6,301 & 1 & 6 & 0 \\
\hline
\end{tabular}


Geospatial Analysis of Renewable Energy Technical Potential on Tribal Lands

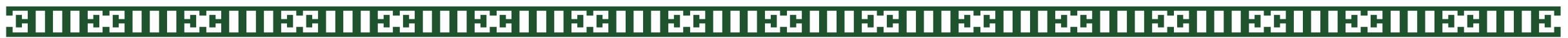

\begin{tabular}{|c|c|c|c|c|c|c|c|c|c|}
\hline Tribal Land & State & $\begin{array}{l}\text { Unidentified } \\
\text { Hydrothermal } \\
\text { Potential } \\
\text { Annual } \\
\text { Generation } \\
\text { (MWh) }\end{array}$ & $\begin{array}{l}\text { Unidentified } \\
\text { Hydrothermal } \\
\text { Potential } \\
\text { Installed } \\
\text { Capacity } \\
\text { (MW) }\end{array}$ & $\begin{array}{l}\text { Hydropower } \\
\text { Generation } \\
\text { Potential } \\
\text { (MWh) }\end{array}$ & $\begin{array}{l}\text { Hydropower } \\
\text { Capacity } \\
\text { Potential } \\
\text { (MW) }\end{array}$ & $\begin{array}{l}\text { Biopower } \\
\text { from Solid } \\
\text { Residuesa } \\
\text { (MWh) }\end{array}$ & $\begin{array}{l}\text { Biopower } \\
\text { from Solid } \\
\text { Residues } \\
(\mathrm{MW})\end{array}$ & $\begin{array}{l}\text { Biopower } \\
\text { from } \\
\text { Gaseous } \\
\text { Residues }^{b} \\
\text { (MWh) } \\
\end{array}$ & $\begin{array}{l}\text { Biopower } \\
\text { from } \\
\text { Gaseous } \\
\text { Residues } \\
\text { (MW) }\end{array}$ \\
\hline Skull Valley & UT & 15,562 & 2 & - & - & - & - & 0 & 0 \\
\hline Smith River Rancheria & $\mathrm{CA}$ & 0 & 0 & - & - & 8 & 0 & 0 & 0 \\
\hline Soboba & $\mathrm{CA}$ & 263 & 0 & 854 & 0 & 165 & 0 & 64 & 0 \\
\hline Southern Ute & $\mathrm{NM}, \mathrm{CO}$ & 188,245 & 24 & 243,721 & 56 & 1,978 & 0 & 144 & 0 \\
\hline Spokane & WA & 12,184 & 2 & 16,571 & 4 & 66,932 & 8 & 18 & 0 \\
\hline Squaxin Island & WA & 4 & 0 & - & - & 1,159 & 0 & 2 & 0 \\
\hline St. Croix & WI & - & - & - & - & 278 & 0 & 1 & 0 \\
\hline St. Regis Mohawk & NY & - & - & 3,293 & 1 & 2,257 & 0 & 21 & 0 \\
\hline Standing Rock & SD, ND & - & - & 18,638 & 4 & 24,045 & 3 & 64 & 0 \\
\hline Stewarts Point Rancheria & $\mathrm{CA}$ & 16 & 0 & - & - & 5 & 0 & 0 & 0 \\
\hline Stillaguamish & WA & 0 & 0 & - & - & 7 & 0 & 0 & 0 \\
\hline Stockbridge-Munsee & WI & - & - & - & - & 74 & 0 & 1 & 0 \\
\hline Sulphur Bank (El-Em) Rancheria & $\mathrm{CA}$ & 76 & 0 & - & - & - & - & 0 & 0 \\
\hline Summit Lake & NV & 10,851 & 1 & - & - & - & - & 0 & 0 \\
\hline Susanville & $\mathrm{CA}$ & 79 & 0 & - & - & 176 & 0 & 0 & 0 \\
\hline Swinomish & WA & 39 & 0 & 3,080 & 1 & 1,769 & 0 & 22 & 0 \\
\hline Sycuan & $\mathrm{CA}$ & 5 & 0 & - & - & - & - & 12 & 0 \\
\hline Table Bluff Rancheria & $\mathrm{CA}$ & - & - & - & - & 5 & 0 & 0 & 0 \\
\hline Table Mountain Rancheria & $\mathrm{CA}$ & 1 & 0 & - & - & 6 & 0 & 0 & 0 \\
\hline Taos Pueblo & NM & 46,205 & 6 & 16,518 & 4 & 985 & 0 & 62 & 0 \\
\hline Te-Moak & NV & 14,860 & 2 & 6,340 & 1 & 169 & 0 & 1 & 0 \\
\hline Tesuque Pueblo & NM & 5,948 & 1 & 635 & 0 & 58 & 0 & 9 & 0 \\
\hline To'Hajillee Chapter, Navajo Nation & NM & 11,434 & 1 & 398 & 0 & 8 & 0 & 10 & 0 \\
\hline Tohono O'odham & $\mathrm{AZ}$ & 510,243 & 65 & - & - & 7,512 & 1 & 296 & 0 \\
\hline Tonawanda & NY & - & - & 779 & 0 & 156 & 0 & 5 & 0 \\
\hline Torres-Martinez & $\mathrm{CA}$ & 10,284 & 1 & 152 & 0 & 1,160 & 0 & 10 & 0 \\
\hline Trinidad Rancheria & $\mathrm{CA}$ & - & - & - & - & 42 & 0 & 0 & 0 \\
\hline Tulalip & WA & 62 & 0 & 815 & 0 & 9,470 & 1 & 164 & 0 \\
\hline Tule River & $\mathrm{CA}$ & 140 & 0 & 23,717 & 5 & 788 & 0 & 76 & 0 \\
\hline Tunica-Biloxi & $\mathrm{LA}$ & - & - & - & - & 141 & 0 & 0 & 0 \\
\hline Tuolumne Rancheria & $\mathrm{CA}$ & 1 & 0 & 926 & 0 & 83 & 0 & 1 & 0 \\
\hline Turtle Mountain & $\mathrm{ND}, \mathrm{MT}$ & 0 & 0 & - & - & 6,268 & 1 & 34 & 0 \\
\hline Tuscarora & NY & - & - & - & - & 708 & 0 & $\begin{array}{r}440,92 \\
5\end{array}$ & 56 \\
\hline Twenty-Nine Palms & $\mathrm{CA}$ & 18 & 0 & - & - & - & - & 0 & 0 \\
\hline Uintah and Ouray & UT & 78,807 & 10 & 442,276 & 101 & 11,811 & 1 & 335 & 0 \\
\hline
\end{tabular}


Geospatial Analysis of Renewable Energy Technical Potential on Tribal Lands

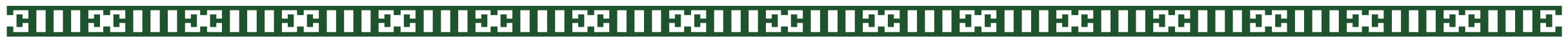

\begin{tabular}{|c|c|c|c|c|c|c|c|c|c|}
\hline Tribal Land & State & $\begin{array}{l}\text { Unidentified } \\
\text { Hydrothermal } \\
\text { Potential } \\
\text { Annual } \\
\text { Generation } \\
\text { (MWh) }\end{array}$ & $\begin{array}{l}\text { Unidentified } \\
\text { Hydrothermal } \\
\text { Potential } \\
\text { Installed } \\
\text { Capacity } \\
\text { (MW) }\end{array}$ & $\begin{array}{l}\text { Hydropower } \\
\text { Generation } \\
\text { Potential } \\
\text { (MWh) }\end{array}$ & $\begin{array}{l}\text { Hydropower } \\
\text { Capacity } \\
\text { Potential } \\
\text { (MW) }\end{array}$ & $\begin{array}{l}\text { Biopower } \\
\text { from Solid } \\
\text { Residuesa } \\
\text { (MWh) }\end{array}$ & $\begin{array}{l}\text { Biopower } \\
\text { from Solid } \\
\text { Residues } \\
\text { (MW) }\end{array}$ & $\begin{array}{l}\text { Biopower } \\
\text { from } \\
\text { Gaseous } \\
\text { Residues }^{b} \\
\text { (MWh) }\end{array}$ & $\begin{array}{l}\text { Biopower } \\
\text { from } \\
\text { Gaseous } \\
\text { Residues } \\
\text { (MW) }\end{array}$ \\
\hline Umatilla & OR & 3,998 & 1 & 57,403 & 13 & 31,490 & 4 & 34 & 0 \\
\hline Upper Lake Rancheria & $\mathrm{CA}$ & 119 & 0 & - & - & - & - & 0 & 0 \\
\hline Upper Sioux Community & $\mathrm{MN}$ & - & - & - & - & 653 & 0 & 0 & 0 \\
\hline Upper Skagit & WA & 1 & 0 & - & - & 22 & 0 & 0 & 0 \\
\hline Ute Mountain & NM, UT, CO & 40,583 & 5 & 34,258 & 8 & 5,442 & 1 & 27 & 0 \\
\hline Vermillion Lake & $\mathrm{MN}$ & - & - & - & - & 137 & 0 & 0 & 0 \\
\hline Viejas Rancheria & $\mathrm{CA}$ & 15 & 0 & - & - & - & - & 3 & 0 \\
\hline Walker River & NV & 246,481 & 31 & 16,585 & 4 & - & - & 14 & 0 \\
\hline Warm Springs & OR & 405,953 & 51 & 130,737 & 30 & 35,935 & 5 & 31 & 0 \\
\hline Washoe & NV & 687 & 0 & 10,030 & 2 & 121 & 0 & 3 & 0 \\
\hline White Earth & $\mathrm{MN}$ & - & - & 3,357 & 1 & 138,785 & 18 & 115 & 0 \\
\hline White Mountain & $\mathrm{AZ}$ & 119,240 & 15 & 115,435 & 26 & 14,148 & 2 & 182 & 0 \\
\hline Wind River & WY & 47,999 & 6 & 350,640 & 80 & 6,349 & 1 & 183 & 0 \\
\hline Winnebago & IA, NE & - & - & 48,821 & 11 & 76,709 & 10 & 22 & 0 \\
\hline Winnemucca Colony & NV & 350 & 0 & - & - & 13 & 0 & 0 & 0 \\
\hline Woodfords Community & $\mathrm{CA}$ & 89 & 0 & - & - & - & - & 0 & 0 \\
\hline XL Ranch & $\mathrm{CA}$ & 8,312 & 1 & 2,726 & 1 & 117 & 0 & 1 & 0 \\
\hline Yakama & WA & 155,549 & 20 & 669,640 & 153 & 274,750 & 35 & 329 & 0 \\
\hline Yankton & $\mathrm{NE}, \mathrm{SD}$ & - & - & 5,029 & 1 & 114,257 & 14 & 55 & 0 \\
\hline Yavapai & $\mathrm{AZ}$ & 197 & 0 & - & - & 639 & 0 & 8 & 0 \\
\hline Yawapa Apache & AZ & 1,658 & 0 & 14,108 & 3 & 190 & 0 & 74,323 & 9 \\
\hline Yerington & NV & 268 & 0 & - & - & 9 & 0 & 0 & 0 \\
\hline Yomba & NV & 1,941 & 0 & 172 & 0 & - & - & 0 & 0 \\
\hline Ysleta Del Sur Pueblo & TX & - & - & - & - & 15 & 0 & 1 & 0 \\
\hline Yurok & $\mathrm{CA}$ & 642 & 0 & 912 & 0 & 25,962 & 3 & 6 & 0 \\
\hline Zia Pueblo & NM & 34,064 & 4 & 1,864 & 0 & 38 & 0 & 6 & 0 \\
\hline Zuni Pueblo & $\mathrm{NM}, \mathrm{AZ}$ & 44,632 & 6 & 7,926 & 2 & 3,457 & 0 & 67 & 0 \\
\hline
\end{tabular}

${ }^{a}$ Solid residues are represented by forest, crop, primary mill, and urban wood residues. Generation estimated assuming $1.1 \mathrm{MWh} / \mathrm{bone}$ dry tonne of residue.

${ }^{\mathrm{b}}$ Gaseous residues are represented by landfill and domestic wastewater residues. Generation estimated assuming $4.7 \mathrm{MWh} /$ tonne of $\mathrm{CH} 4 \mathrm{produced}$ by the residues. 